\title{
The Influence of Micronutrients in Cell Culture: A Reflection on Viability and Genomic Stability
}

\author{
Ana Lúcia Vargas Arigony, ${ }^{1}$ Iuri Marques de Oliveira, \\ Miriana Machado, ${ }^{1,2}$ Diana Lilian Bordin, ${ }^{1}$ Lothar Bergter, ${ }^{2}$ \\ Daniel Prá, ${ }^{1,3}$ and João Antonio Pêgas Henriques ${ }^{1,2,4}$ \\ ${ }^{1}$ Laboratório de Reparação de DNA em Eucariotos, Departamento de Biofísica/Centro de Biotecnologia, UFRGS, \\ Avenida Bento Gonçalves 9500, Prédio 43422, Setor IV, Campus do Vale, 91501-970 Porto Alegre, RS, Brazil \\ ${ }^{2}$ Instituto de Educação para Pesquisa, Desenvolvimento e Inovação Tecnológica-ROYAL, Unidade GENOTOX-ROYAL, Centro de \\ Biotecnologia, UFRGS, Avenida Bento Gonçalves 9500, Prédio 43421, Setor IV, Campus do Vale, 91501-970 Porto Alegre, RS, Brazil \\ ${ }^{3}$ PPG em Promoção da Saúde, Universidade de Santa Cruz do Sul (UNISC), Avenida Independência 2293, \\ 96815-900 Santa Cruz do Sul, RS, Brazil \\ ${ }^{4}$ Instituto de Biotecnologia, Departamento de Ciências Biomédicas, Universidade de Caxias do Sul (UCS), \\ Rua Francisco Getúlio Vargas 1130, 95070-560 Caxias do Sul, RS, Brazil
}

Correspondence should be addressed to João Antonio Pêgas Henriques; pegas.henriques@gmail.com

Received 7 January 2013; Revised 23 April 2013; Accepted 3 May 2013

Academic Editor: Vanina Heuser

Copyright (C) 2013 Ana Lúcia Vargas Arigony et al. This is an open access article distributed under the Creative Commons Attribution License, which permits unrestricted use, distribution, and reproduction in any medium, provided the original work is properly cited.

\begin{abstract}
Micronutrients, including minerals and vitamins, are indispensable to DNA metabolic pathways and thus are as important for life as macronutrients. Without the proper nutrients, genomic instability compromises homeostasis, leading to chronic diseases and certain types of cancer. Cell-culture media try to mimic the in vivo environment, providing in vitro models used to infer cells' responses to different stimuli. This review summarizes and discusses studies of cell-culture supplementation with micronutrients that can increase cell viability and genomic stability, with a particular focus on previous in vitro experiments. In these studies, the cell-culture media include certain vitamins and minerals at concentrations not equal to the physiological levels. In many common culture media, the sole source of micronutrients is fetal bovine serum (FBS), which contributes to only 5-10\% of the media composition. Minimal attention has been dedicated to FBS composition, micronutrients in cell cultures as a whole, or the influence of micronutrients on the viability and genetics of cultured cells. Further studies better evaluating micronutrients' roles at a molecular level and influence on the genomic stability of cells are still needed.
\end{abstract}

\section{Introduction}

Micronutrients, essential nutrients that are needed in small amounts, are as important for life as macronutrients. Micronutrients comprise all of the vitamins, such as $\mathrm{A}, \mathrm{D}$, and $\mathrm{E}$, as well as the minerals, such as calcium, zinc, and iron. The in vivo role of micronutrients is well established, and several studies have examined the effects of micronutrients on genomic stability [1-21]. Approximately 40 micronutrients are required in the human diet, and for each micronutrient, proper metabolism demands an optimal level of intake. A micronutrient deficiency distorts the metabolism in numerous and complicated ways, many of which may lead to DNA damage.

Micronutrients are required for optimal macronutrient metabolism because of micronutrients' critical role in intermediate metabolism. Invariably, metabolism requires the concomitant involvement of one or more vitamins and minerals. Chronic degenerative disease etiology and the rate of pathogenesis are thus intimately associated with micronutrient imbalances. Nutrition research has recently highlighted the role of several nutrients in regulating the genomic 
machinery [22]. More specifically, a number of vitamins and micronutrients are substrates and/or cofactors in the metabolic pathways regulating DNA synthesis and/or repair and gene expression [23]. A deficiency in such nutrients may result in the disruption of genomic integrity and alteration of DNA methylation, thus linking nutrition with the modulation of gene expression. In many cases, the response to a nutrient deficiency also seems to be genotype specific. Genenutrient interactions are thus a fascinating example of physiological responses to the environment/diet at the molecular level [22].

Minerals and vitamins are indispensable to DNA metabolic pathways $[24,25]$. Although there is still no clear evidence for a diet that optimally protects against DNA damage, in terms of either proportions or combinations of specific micronutrients, many studies that conducted in vitro and in animal models have demonstrated the roles of micronutrients in maintaining genomic stability. For example, vitamins $\mathrm{C}$ and $\mathrm{E}$ deficiencies are known to cause DNA oxidation and chromosomal damage $[26,27]$. Vitamin D exhibits antioxidant activity, stabilizes chromosomal structure, and prevents DNA double-strand breaks [28]. Similarly, magnesium is an essential cofactor in DNA metabolism that plays a role in maintaining the high fidelity of DNA transcription [29]. Whereas either an excess of or a deficiency in iron may cause DNA breaks [30], a carotenoid-rich diet reduces DNA damage [31], but excess retinol may be carcinogenic in certain individuals [32]. In a final example, vitamin B-12 deficiency is associated with the formation of micronuclei $[5,24]$, and reduced transcobalamin II in the serum is associated with chromosomal abnormalities [33].

Given the importance of micronutrients in vitro, the optimization of cell viability and genomic stability warrants further studies. Cell-culture media mimicking the in vivo environment may help to generate in vitro models of a cell's response to different stimuli. The composition of these media includes certain vitamins and minerals, but unfortunately, in many common culture media, the only source of micronutrients is fetal bovine serum (FBS), which contributes to only $5-10 \%$ of the media composition. Moreover, the appropriate proportion of micronutrients is not always provided because the precise composition of each batch of FBS is in fact extremely variable [34].

Certain micronutrients, such as calcium, folate, magnesium, and iron, have been reported as key elements in cellular processes, including the proliferation, survival, and even differentiation of cell cultures [35-38]. However, the particular concentration of micronutrients in a culture as well as the cell type may trigger different responses. Further studies of micronutrients' roles at a molecular level and influence on genomic stability are still required.

\section{Aims and Scope}

This review summarizes and discusses studies showing the influence of some micronutrients on cell viability and genomic stability, with a particular focus on in vitro models. In vivo evidences are presented to illustrate the relevance of the nutrients to genomic stability. Papers were retrieved from
PubMed using the following search terms: micronutrients, vitamins, minerals, cell culture, proliferation, viability, and genomic stability. Additional publications were collected by cross-referencing the primary articles retrieved. The review does not aim to include all nutrients that could influence genomic stability; then, only the following nutrients were included vitamins $\mathrm{A}, \mathrm{B} 7, \mathrm{~B} 9, \mathrm{~B} 12, \mathrm{C}$, and $\mathrm{E}$ and minerals $\mathrm{Cu}$, $\mathrm{Fe}, \mathrm{Mg}$, Se, and Zn. According to Friso and Choi [39], an imbalance of such dietary nutrients as folate, zinc, vitamin C, and selenium can alter genomic and/or gene-specific DNA methylation, resulting in many different molecular effects on gene expression and integrity, in turn affecting cell growth, tissue differentiation, cancer incidence, and aging. To better address the selected micronutrients' effects in cell viability and genomic stability, we considered the information available regarding either their deficiency or excess.

\section{Micronutrients and Their Influence on Genomic Stability}

DNA damage is one of the most important factors that can compromise homeostasis, resulting in chronic (e.g., atherosclerosis) and even degenerative diseases, including Alzheimer's disease (AD) and certain types of cancer [40]. A deficiency in or imbalance of certain micronutrients has been described as mimicking radiation or chemicals, causing single- and double-strand breaks (SB) or lesions in DNA, or even both [20].

In Table 1, micronutrients whose imbalances cause DNA damage are listed, as well as the nutrients' food sources and possible health effects. In general, micronutrients can either act directly on the genome to prevent mutations or protect the genome indirectly by serving as enzyme cofactors in the cellular processes that modulate transformation [41, 42]. Therefore, any imbalance may result in a degree of DNA damage.

The role of diet in determining genomic stability is more important than previously imagined. It has been found that diet affects all pathways relevant to genomic stability, including exposure to dietary carcinogens, activation and detoxification of carcinogens, DNA repair, DNA synthesis, and cell apoptosis [23, 43]. All of these critical pathways are dependent not only on enzymes but also on substrates and cofactors, a few of which are only available at the right concentration when the dietary intake of key minerals and vitamins is adequate [44]. As a result, a dietary deficiency in certain micronutrients required for DNA maintenance may exert effects similar to inherited genetic disorders that impair the activity of enzymes required for genomic stability [23, 4547]. Additionally, such a deficiency may damage DNA to a similar extent as significant exposure to known carcinogens, such as ionizing radiation [43].

3.1. Vitamin A. Vitamin A is also referred to as retinoic acid, retinol, retinal, $\alpha$ - and $\beta$-carotene, lycopene, lutein, zeaxanthin, $\beta$-cryptoxanthin, or astaxanthin. The role of vitamin A and provitamin A (carotenoids) in DNA damage has recently been reviewed by Azqueta and Collins [65]. The well-established antioxidant properties of vitamin A have 


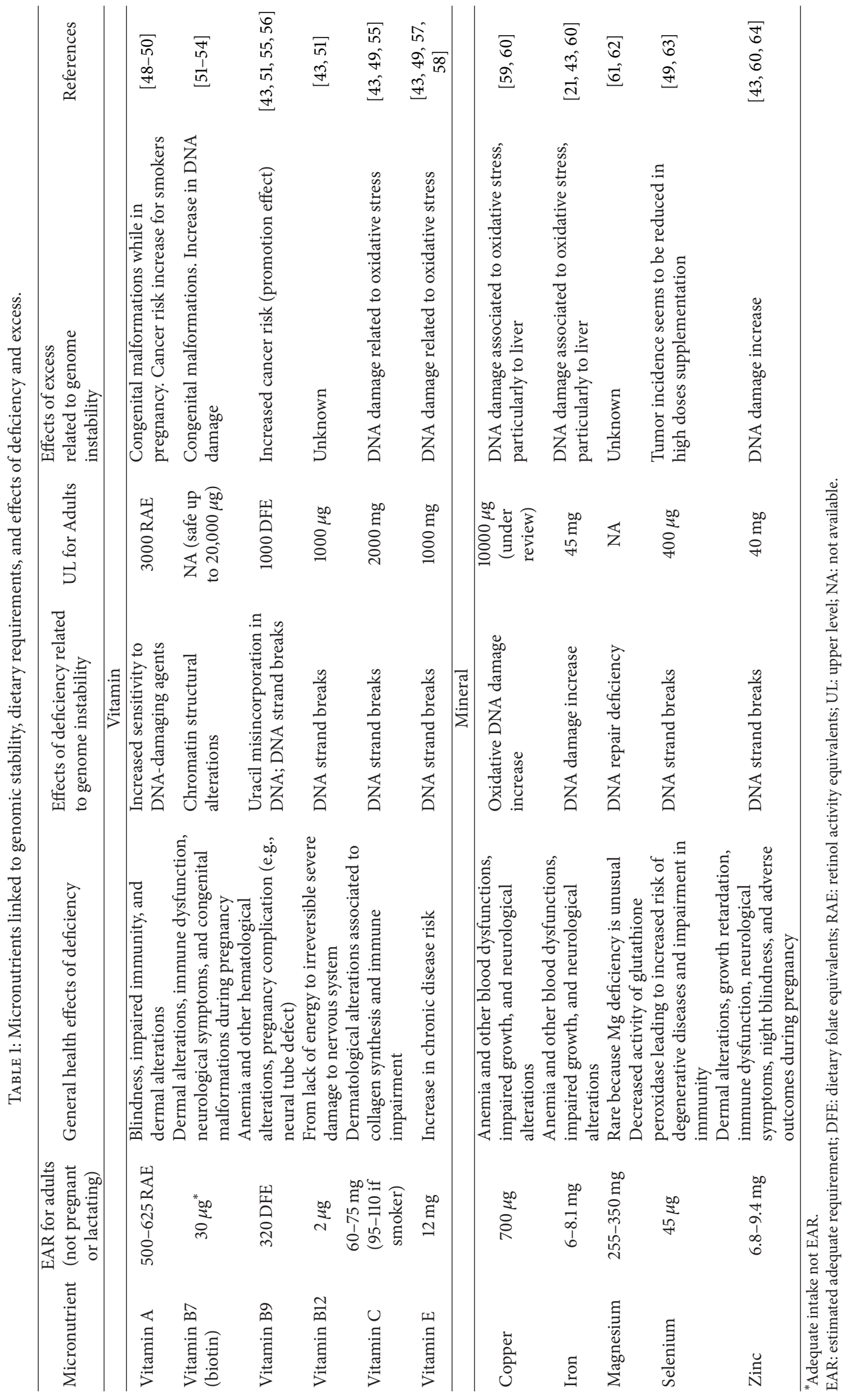


facilitated studies measuring oxidative damage both in vivo, in animal studies and human clinical trials, and in vitro. Whereas high concentrations of provitamin A carotenoids can cause DNA damage, perhaps by acting as prooxidants, nonvitamin A carotenoids that can significantly reduce such damage [66].

The functions of vitamin A are related to night, day, and color vision; epithelial-cell integrity against infections; the immune response; hemopoiesis; skeletal growth; male and female fertility; embryogenesis. Paradoxically, either an excess of or a deficiency in retinoic acid results in similar malformations in certain organs, including the mammalian kidney [67]. Many eye pathologies are due to vitamin A deficiency, including night blindness, conjunctival xerosis and corneal injuries. Similarly, hypervitaminosis A, resulting from the storage of excess vitamin A in the body, can damage various systems. Very large doses of vitamin A, especially in young children, can increase the intracranial pressure, leading to headache, nausea, and vomiting [68]. It has also been established that adequate vitamin $\mathrm{A}$ intake is required for normal organogenesis, immune function, tissue differentiation, and vision. Given these requirements, vitamin A deficiency, which is widespread in the developing world, is responsible for at least one million instances of unnecessary death and blindness each year [69].

3.2. Vitamin B7. Vitamin B7, also known as biotin, acts as a cofactor for the biotin-dependent enzymes pyruvate carboxylase, propionyl-CoA carboxylase, crotonyl-CoA carboxylase, and two isozymes of acetyl-CoA carboxylase [70]. These enzymes catalyze key steps in important metabolic pathways, including fatty acid biosynthesis, gluconeogenesis, and amino acid metabolism [71]. Vitamin B7 deficiency due to inadequate dietary intake or congenital defects in biotin absorption or metabolism results in the inactivation of all five biotindependent enzymes. This condition is known as multiple carboxylase deficiency (MCD) [72, 73], whose symptoms include ketoacidosis, lactic acidosis, feeding difficulties, skin rashes, and neurological abnormalities, such as subependymal cysts, hypotonia, seizures, and ataxia. In severe cases, or if MCD is left untreated, the condition can lead to coma or death [74].

It has been demonstrated that biotin plays a role in DNAstrand breaks and the cellular response to strand breaks (SB). More specifically, biotin supplementation increased DNA breaks in cell cultures, although it is unknown whether this finding is relevant to whole organisms [75]. In contrast, in vivo, a high biotin intake in combination with a low intake of multiple other nutrients has been associated with increased genomic stability [53]. Biotin deficiency rarely occurs spontaneously in animals, including humans [76], but can be induced by consuming large amounts of raw egg white, which contains avidin, known to inhibit biotin absorption from the intestinal tract, or by taking anticonvulsants [77].

3.3. Vitamin B9. A deficiency in vitamin B9, also known as folic acid or folate, is common in people who consume few fruits and vegetables. Vitamin B9, as well as other vitamins from the $\mathrm{B}$ complex, plays an important role in genomic stability, and a deficiency can cause chromosomal breaks in human genes [78]. Vitamin B9 deficiency can also lead to (a) an elevated rate of DNA damage and altered DNA methylation, both of which are risk factors for cancer [7880], possibly including colon cancer [81] or (b) an increased homocysteine concentration, an important risk factor for cardiovascular disease [82]. These defects may also play a significant role in developmental and neurological abnormalities $[78,79]$. However, in animals with existing preneoplastic or neoplastic lesions, folicacid supplementation increases the tumor burden [83]. In contrast, the adequate intake of vitamin B9 can increase genomic stability and possibly reduce cancer risk [84-87] because vitamin B9 is a key carbon donor during nucleotide biosynthesis [88].

3.4. Vitamin B12. Vitamin B12, or cyanocobalamin, deficiency is associated with pernicious anemia and neurological pathologies varying from a minor decrease in cognitive function to neurodegenerative disorders, although the role of vitamin B12 in these conditions requires further investigation $[89,90]$. The lack of understanding of the underlying molecular mechanisms may be due to the experimental limitations of the available classical cell-culture models [89]. Nevertheless, vitamin B12 is known to play an important role in genomic stability, and a deficiency in vitamin B12 can lead to DNA damage [81]. Vitamin B12 is also required for the synthesis of methionine and $S$-adenosyl methionine, the common methyl donor required for the maintenance of the DNA methylation patterns that determine gene expression and DNA conformation [91].

Despite controversies in the literature regarding the prevalence of vitamin B12 deficiency, this deficiency seems to be more common among people aged 65-76 years [92]. However, the symptoms of vitamin B12 deficiency caused by poor diet, digestive problems, and/or inadequate absorption in elderly people can be nonspecific, rendering a diagnosis more difficult. Furthermore, neurological symptoms may appear before anemia; in fact, only approximately $60 \%$ of elderly people with vitamin B12 deficiency are anemic [92, 93]. In cell-culture models, sufficient vitamin B12 can be provided to the cells by the FBS [89].

3.5. Vitamin C. Vitamin C, also known as ascorbate or ascorbic acid, is a micronutrient required for innumerable biological functions, specifically serving as a cofactor for certain important enzymes [94]. One type enzyme is the prolyl hydroxylases, which play a role in collagen biosynthesis and the downregulation of hypoxia-inducible factor- (HIF-) 1, a transcription factor that regulates many genes responsible for tumor growth, energy metabolism, and neutrophil function and apoptosis. Vitamin C-dependent inhibition of the HIF pathway may provide alternative or additional approaches to controlling tumor progression, infection, and inflammation [94].

As vitamin $C$ exhibits antioxidant properties that provide protection against oxidative stress-induced cell damage by scavenging reactive oxygen species (ROS), the effects of this vitamin on cancer chemoprevention $[95,96]$ and cancer treatment [97] as well as sepsis [98] and neurodegenerative 
diseases (e.g., Alzheimer's disease) [99] have been studied. In fact, ingesting inadequate levels of vitamin $\mathrm{C}$ can mimic radiation exposure. In the literature, numerous human supplementation studies have used biomarkers of oxidative damage to DNA, lipids (lipid oxidation releases mutagenic aldehydes), and protein. Although these studies have yielded both positive and negative results, if the fact that blood-cell saturation occurs at approximately $100 \mathrm{mg}$ /day is taken into consideration, the evidence suggests that this level of vitamin C intake minimizes DNA damage [20]. Unfortunately, vitamin $\mathrm{C}$ deficiency is common in poor communities, so measures to improve the consumption of vitamin C-rich foods should be considered [100].

3.6. Vitamin E. Vitamin E, which comprises compounds from the tocopherol and tocotrienol families, is required to prevent peripheral neuropathy and hemolytic anemia in humans, which arise due to vitamin E deficiency. Vitamin E functions as a vital lipid-soluble antioxidant, scavenging hydroperoxyl radicals in the lipid milieu. The human symptoms of vitamin E deficiency suggest that this vitamin's antioxidant properties play a major role in protecting erythrocyte membranes and nervous tissues [94]. Additionally, these antioxidant properties play a role in genomic stability, particularly because vitamin $\mathrm{E}$ is a potent peroxyl radical scavenger. Vitamin $\mathrm{E}$ is also a chain-breaking antioxidant that prevents the propagation of free radicals in membranes and plasma lipoproteins [101].

Recently, Ni and Eng [102] demonstrated that $\alpha$-tocopherol can selectively protect SDH $\left(\operatorname{var}^{+}\right)$cells from oxidative damage and apoptosis and rebalance the redox metabolites nicotinamide adenine dinucleotide $\left(\mathrm{NAD}^{+}\right.$and $\mathrm{NADH}$ ). Another interesting recent study [103] evaluated the amount of the oxidation product 8 -oxo-7,8-dihydro- $2^{\prime}$-deoxyguanosine (8-oxodG) formed from the DNA nucleoside deoxyguanosine $(\mathrm{dG})$ after vitamin exposure. In the case of vitamin $\mathrm{E}$, no DNA damage was induced in cultured cells. Taken together, these results reinforce the role of this vitamin in maintaining DNA integrity and stability. Although the direct comparison of the study outcomes is complicated by varying definitions of vitamin E deficiency, the available data suggest that children and the elderly are most vulnerable to this deficiency and that men may be at higher risk than women [104].

3.7. Copper. Copper is an essential trace element, serving as a cofactor for many enzymes in different biological processes. In contrast to iron, the copper concentration not only in the blood but also in individual organs is maintained at constant levels beginning in early childhood, indicating the presence of robust homeostatic mechanisms [105]. Adequate copper intake permits the normal utilization of dietary iron, as intestinal iron absorption, iron release from stores (e.g., in the macrophages of the liver and spleen), and iron incorporation into hemoglobin are copper-dependent processes. In addition to preventing anemia, copper assists in blood coagulation and blood-pressure control; the crosslinking of connective tissue in the arteries, bones, and heart; defense against oxidative damage; energy transformation; the myelination of the brain and spinal cord; reproduction; hormone synthesis. In contrast, inadequate copper intake has adverse effects on the metabolism of cholesterol and glucose, blood pressure control and heart function, bone mineralization, and immunity [106].

The excessive accumulation of copper in the body can contribute to the development of cancer due to copper's role in causing DNA damage [107]. Curiously, in addition to the robust mechanisms maintaining copper homeostasis and copper's rapid excretion, mammals express copper-dependent enzymes that are central players in antioxidant defense. Thus, whereas copper can induce ROS formation when involved in Fenton-like or Haber-Weiss reactions, copperdependent processes can also help to clear ROS [105]. For further information on the relationship between copper and DNA damage, please refer to the recent review published by Linder [105].

3.8. Iron. Iron is a crucial nutritional element for all life forms that plays a critical role in the cell, including electron transport and cellular respiration, proliferation and differentiation, and the regulation of gene expression [3]. Iron can undergo univalent redox reactions, resulting in oxidized and reduced forms known as ferric $\left(\mathrm{Fe}^{3+}\right)$ and ferrous $\left(\mathrm{Fe}^{2+}\right)$ iron, respectively. Due to iron's oxireduction, which can contribute to ROS generation, as well as iron's role in Fenton and HaberWeiss reactions, this nutrient is also potentially deleterious. These reactions occur when an inorganic nutrient, such as $\mathrm{Fe}^{2+}$ or $\mathrm{Cu}^{+}$, is in excess and donates an electron to $\mathrm{H}_{2} \mathrm{O}_{2}$, leading to $\mathrm{OH}$ production. The ROS generated by Fenton chemistry can contribute to major pathologies, such as cancer, atherosclerosis, and neurodegenerative diseases [38].

Free radicals can cause serious damage to the genome. Depending on the dose and type, inorganic nutrients can protect against or contribute to oxidative stress [108]. Peroxidases and especially catalase, which use heme iron as a cofactor, decompose $\mathrm{H}_{2} \mathrm{O}_{2}$. If the resultant reactive species are not efficiently removed, these species can induce the formation of the more active $\mathrm{OH}$ or peroxynitrite, which may result in DNA oxidation. Therefore, deficiencies in such nutrientdependent antioxidant enzymes can increase oxidative stress and favor the genomic instability [109].

In addition, iron is a cofactor of many important enzymes related to DNA repair mainly as clusters of iron sulphur. For example, the glycosylases MutyH and NTHL1 involved in base excision repair (BER) and mismatch repair (MMR) and the helicases ERCC2 and BACH1 acting in the nucleotide excision repair (NER) possess iron-sulphur clusters in their structure $[110,111]$. The increased DNA damage sensitivity in cells with impaired $\mathrm{Fe} / \mathrm{S}$ protein biogenesis may include the loss of nucleotide excision repair because maturation of XPD is defective. Since the Fe/S cluster of XPD is required for its DNA helicase activity in vitro [110].

Although excess iron can cause oxidative DNA damage in rats and has been associated with an increased risk of cancer and heart disease in humans [20], iron deficiency also appears 
to lead to oxidative DNA damage and is associated with cognitive dysfunction in children. The importance of iron in normal neurological function has been well established, as neurons require iron for many physiological processes, including electron transport and axonal myelination, and as a cofactor for many enzymes involved in neurotransmitter synthesis $[112,113]$. In contrast, inadequate iron intake results in anemia, immune dysfunction, and adverse pregnancy outcomes, such as premature birth. Maintaining physiological iron levels via dietary intake is thus mandatory for health. However, iron deficiency is still very common in the human population, particularly among children and pregnant women [114].

3.9. Magnesium. Magnesium is indispensable to life, as this micronutrient is involved in many important biological processes. Magnesium has multiple functions in all cellular processes, including DNA replication and protein synthesis, and also serves as a cofactor for DNA-repair proteins and in the maintenance of a cell's redox status, cell-cycle regulation, and apoptosis [29]. Magnesium deficiency or the displacement of $\mathrm{Mg}^{2+}$ by other toxic, divalent metal ions leads to increased genomic instability, which has been implicated in many diseases [115] and may result in inhibited DNA repair, oxidative stress, accelerated aging, and increased cancer risk $[29,116]$. Studies have indicated that higher magnesium consumption may protect against certain inflammatory disorders, such as insulin resistance [117], hypertension [118], diabetes mellitus [119], and cardiovascular disease [118].

Magnesium is not genotoxic at physiologically relevant concentrations and in fact maintains low mutation frequencies by facilitating high-fidelity replication and by supporting all DNA-repair processes and chromosomal segregation during mitosis [29]. In fact, it is an essential cofactor in NER, BER, and MMR processes, where magnesium is required for the removal of DNA damage [120]. All downstream activities of major base excision repair proteins, such as apurinic/apyrimidinic endonuclease, DNA polymerase beta, and ligases, require magnesium. Thus, this element may act as a regulator for the base excision repair pathway for efficient and balanced repair of damaged bases, which are often less toxic and/or mutagenic than their subsequent repair product intermediates [121]. Magnesium is also important for the fidelity of DNA replication, impacting cell cycle and apoptosis [61].

Animal and human epidemiological studies have demonstrated inverse correlations between magnesium levels and cardiovascular disease [29] or the incidence of certain types of cancer, including colorectal cancer $[122,123]$. Additionally, magnesium deficiency is one risk factor for premature aging [29]. The relationship between magnesium levels and tumorigenesis is more complex, with magnesium deficiency increasing tumor incidence in animals and humans, whereas magnesium promotes the growth of preexisting tumors due to profound changes in magnesium homeostasis in tumor cells. Thus, the protective effects of magnesium are restricted to the early stages of tumor development [29]. According to Ford and Mokdad [124], despite the role of magnesium in maintaining good health, historically, much of the population of the United States has not consumed adequate amounts of this nutrient. Additionally, there are significant racial and ethnic disparities in magnesium intake.

3.10. Selenium. The trace element selenium is another wellestablished micronutrient essential for mammalian health [125]. Selenium is a constituent of the small group of selenocysteine-containing selenoproteins [126], including glutathione peroxidase, thioredoxin reductase, selenoprotein $\mathrm{P}$, and selenoprotein $\mathrm{R}$, which are primarily involved in antioxidant activity and the maintenance of a cell's redox state [127-130]. Due to selenium's key role in redox regulation and antioxidant function, this nutrient is critical for membrane integrity, energy metabolism, and protection against DNA damage [126]. However, in certain cases, selenium can also lead to oxidative DNA damage [20], increased infection risk, and altered mood [131]. Whether selenium exerts positive or negative effects in vivo or in vitro is related to dose. Interest in organoselenide chemistry and biochemistry has increased over the last two decades, mainly because a variety of organoselenium compounds can be used as antioxidants, enzyme inhibitors, neuroprotective, antitumoral, or anti-infectious agents, as well as cytokine inducers and immunomodulators [125, 132-135]. In fact, an interaction with the zinc finger structures of DNA repair proteins may occur by essential trace elements such as certain selenium compounds, which appear to exert anticarcinogenic properties at low concentrations but may compromise genetic stability at higher concentrations [136].

Selenium deficiency alone is not common in developed countries, but an inadequate intake of this mineral has been associated with the development of cancer, asthma, and coronary disease, among other chronic conditions [137]. When required, dietary supplementation must be performed carefully, given the intrinsic toxicity of high selenium levels [138].

3.11. Zinc. Zinc is one of the most important micronutrients due to the prevalence of zinc-dependent enzymes in metabolic processes; zinc's vital role in several bodily functions, such as vision, taste perception, cognition, cell reproduction, growth, and immunity; the beneficial effect of zinc supplementation on many disease states [139]. In fact, zinc is a component of over 300 proteins, including over 100 DNA-binding proteins with zinc fingers, $\mathrm{Cu} / \mathrm{Zn}$ superoxide dismutase, the estrogen receptor, and the synaptic transmission protein [20]. Zinc also has a crucial role in the biology of p53, in that p53 binds to DNA through a structurally complex domain stabilized by zinc atom, possibly increasing the response to anticancer drugs [140].

Zinc deficiency is a health problem in many communities, especially among adolescents, due to the pubertal growth spurt [139]. At the molecular level, there is evidence of a relationship between zinc deficiency and increased chromosomal breaks, possibly due to increased oxidative damage stemming from a loss in the activity of $\mathrm{Cu} / \mathrm{Zn}$ superoxide dismutase or the zinc-containing DNA-repair enzyme Fapy glycosylase, which repairs oxidized guanine [20]. Unfortunately, nearly half of the world's population is at risk of inadequate zinc 
intake, so public health programs are urgently needed to reduce zinc deficiency [139].

3.12. Summary of the Effects of the Selected Micronutrients on Genomic Stability. Taking the preceding discussion and other evidence from the literature into account, the adequate intake of micronutrients seems to have an important role in genomic stability. In contrast, an imbalance of the same micronutrients may also negatively impact the DNA, possibly via oxidative stress, consequently causing or contributing to different human diseases. It is thus highly relevant to elucidate the mechanism underlying the response to and repair of oxidative stress and this mechanism's relationship to the DNA damage response pathways, all of the inorganic nutrients (vitamins and minerals) and disease, including carcinogenesis. An understanding of the possible influences on genomic stability, even in cell culture, is also in current demand.

\section{Cell-Culture Medium and Micronutrients That Increase Genomic Stability: Is the Concentration Relevant?}

According to Ferguson and Fenech [141], the last decade of studies on micronutrients and genomic stability have improved dietary recommendations based on the prevention of DNA damage or the maintenance of genomic integrity. In light of this, the development of in vivo and especially in vitro models to more robustly evaluate DNA damage is necessary.

Table 2 presents interesting data regarding the micronutrients that may interfere with genomic stability and the micronutrient concentration values found in typical cellculture media, FBS, and human serum. Unfortunately, data are not available for all of the micronutrients in the media, and even the proportions of micronutrients in FBS, as an organic product, are not all well characterized. Additionally, as demonstrated by Bryan et al. [34], the concentration of many micronutrients in FBS can vary significantly between batches.

Although cell-culture media attempt to provide an environment similar to the in vivo milieu of cell development, there is an evident imbalance of micronutrients between the media and human serum. Certain micronutrients are present in these media at concentrations higher than those found in human serum (e.g., vitamins B7 and B12), whereas other nutrients are present at significantly lower concentrations than in human serum (e.g., iron and zinc). A recent study [103] called attention to the composition of multivitamin supplements, which may trigger unwanted health outcomes due to the synergistic oxidative effects of the component vitamins and metals. In this research, the vitamins' chemical oxidation potencies were studied by measuring the amount of the oxidation product 8-oxo-7,8-dihydro-2' -deoxyguanosine (8oxodG) formed from the DNA nucleoside deoxyguanosine (dG) after vitamin exposure. The micronutrients evaluated by the authors were the vitamins A, B1, B2, B3, B6, B12, and C; $\beta$-carotene; folic acid; $\alpha$-, $\delta$-, and $\gamma$-tocopherol. The minerals copper, iron and zinc were also examined. All of these micronutrients were tested in cell culture, alone or in combination, taking the human serum levels of each micronutrient into account. The main conclusion reported was that certain vitamins, alone or in combination with metals (e.g., vitamin C and copper), can induce DNA damage. However, cells in culture and in vivo have distinct needs for nutrients and growth factors, as the cells' activity in each environment may differ due to interactions with other cells or parts of the larger organism. Thus, examining physiological concentrations of micronutrients in vitro may not be the most appropriate approach.

As mentioned above, each cell type may have a distinct requirement for micronutrients. Depending of the origin of the cell and its role in vivo, the cell may specifically have a higher affinity for one micronutrient over another. In the case of iron, for example, which is stored in specific tissues, including the spleen, liver, and bone marrow [142], the primary cells or immortal cell lines derived from these tissues may have a greater need for this specific micronutrient. In the case of certain neuronal cells, which require iron for cell development [143], the demand for iron may also be higher than in other cell types. Although the evaluation of micronutrients' influence on DNA damage and integrity as well as on cell development, including the related enzymes and proteins, should be continued, the micronutrient concentrations relevant not only to human but also to cell-culture genomic stability must be considered.

\section{Could Changes in a Culture's Micronutrient Composition Influence the Viability and Genetics of the Cultured Cells?}

Cells are typically maintained at an appropriate temperature and $\mathrm{CO}_{2}$ concentration (usually $37^{\circ} \mathrm{C}$ and $5 \% \mathrm{CO}_{2}$ for mammalian cells) in an incubator. Beyond these parameters, the most commonly varied factor in culture systems is the growth medium. The recipes for growth medium can vary in $\mathrm{pH}$, glucose concentration, growth factors and the presence of other nutrients and micronutrients. The development of synthetic basal formulations for mammalian cell-culture applications has been facilitated by the contributions of many investigators. In particular, the definition of the minimally required nutrients by Harry Eagle in the 1950s spawned an iterative process of continuous modification and refinement of the exogenous environment to cultivate new cell types and support the emerging applications of cultured mammalian cells. This process led to the development of highly potent, basal nutrient formulations capable of sustaining serum-free cell proliferation and biological production [152]. However, the growth factors most often used to supplement cell-culture media are still derived from animal blood, such as FBS. FBS has become the supplement of choice for cell culture-based research, containing an array of proteins, growth factors, and ions necessary for cell viability and proliferation in vitro, including certain vitamins and minerals [153]. Currently, the use of these ingredients is minimized or eliminated wherever possible in favor of chemically defined media, but this substitution is not always possible.

Bryan et al. [34] stated that one of the major obstacles to obtaining human cells of a defined and reproducible 


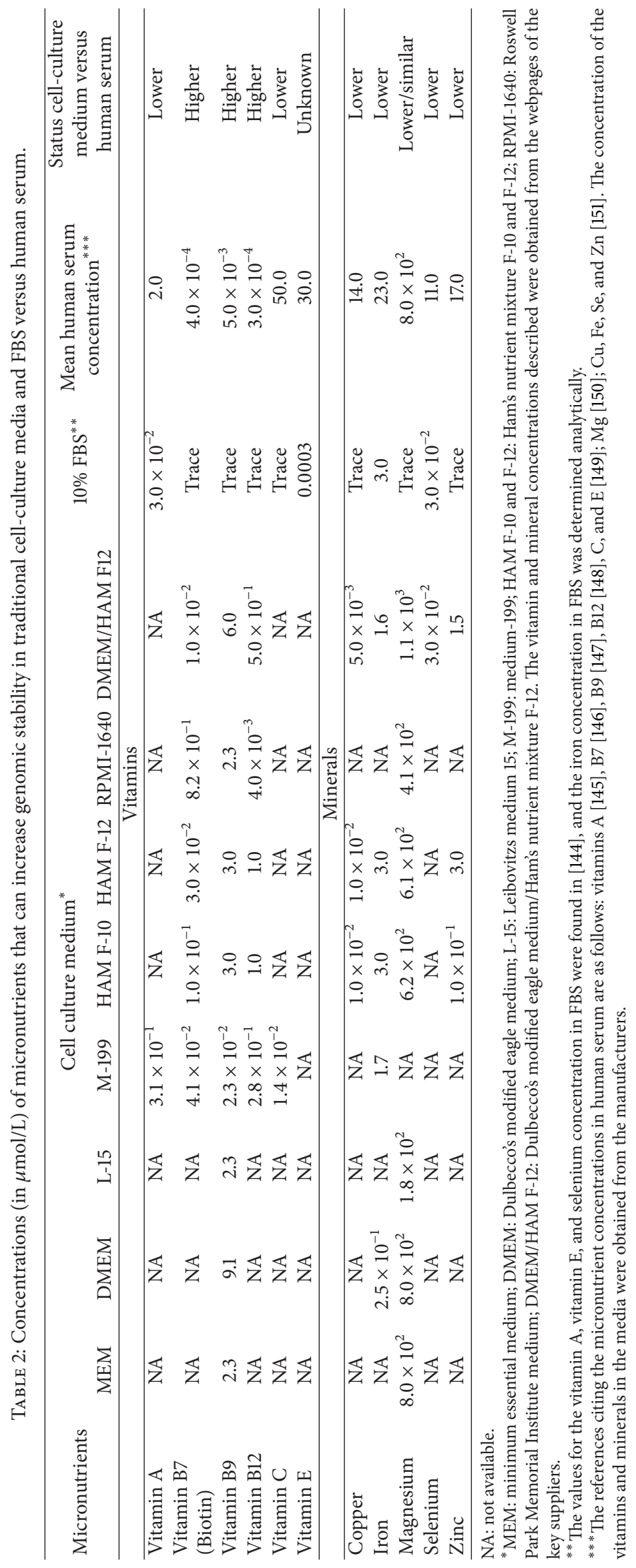


standard, and thus suitable for use in medical therapies, is the routine necessity of supplementing cell-culture media with FBS. In this study, FBS variants were evaluated, in terms of both elemental (micronutrient) composition and the variants' effects on the expression of a group of proteins associated with the antigenicity of primary human umbilical vein endothelial cells (HUVECs). A combination of inductively coupled plasma mass spectrometry (ICPMS) and flow cytometry was used to achieve these experimental objectives. Statistically significant differences in antigenic expression during cell culture were demonstrated for a set of trace elements in FBS (e.g., lithium, boron, magnesium, phosphorus, sulfur, potassium, titanium, vanadium, chromium, manganese, iron, copper, zinc, gallium, and selenium). The lack of reproducibility and the variation in protein expression in the primary human cells was attributed to the FBS supplementation.

Culture conditions for cell lines are known to affect gene expression [154-156], while stem cells grown in different types of serum exhibit variable differentiation and proliferation characteristics $[157,158]$ the same cell line, if cultivated in different conditions, can present different phenotypes. Nevertheless, the cellular requirement for a specific micronutrient is directly correlated with the cell type, the rate of cell grow, and the stage of cell differentiation. In light of this, it is important to observe that minimal attention has been dedicated to the composition of FBS and the micronutrient supplementation of media in cell cultures or the fact that micronutrients can influence the viability and genomic stability of cultured cells.

In Tables 3 and 4, a few examples of the effects of vitamins and minerals in cell culture and on genomic stability, drawn from the literature, are highlighted.

5.1. Vitamin A. For vitamin A, but possibly applicable to many other micronutrients, the studies presented in Table 3, conducted at low concentrations, which tend to show protective effects, whereas higher concentrations are associated with increased DNA damage [65]. This finding is consistent with the known ability of $\beta$-carotene to act as a prooxidant, rather than as an antioxidant, at high concentrations and under high oxygen tension [178]. The physiological concentrations of micronutrients should always be evaluated and, if possible, at least used as a maximum in studies evaluating the viability and genomic stability of cell cultures. However, as can be verified in Table 2, there is a lack of data regarding the presence of vitamin A in cell-culture media.

5.2. Vitamin B7 (Biotin). Biotin plays an important role in regulating gene expression, thus mediating certain aspects of cell biology and fetal development [179]. The effects of biotin deficiency are detailed in Table 3 and are related to decreased rates of cell proliferation, impaired immune function, and abnormal fetal development. An excess of biotin is also mentioned and can exert reproductive and teratogenic effects. However, as can be verified in Table 2, cell-culture media containing higher levels of biotin than human serum are common. More studies evaluating the effects of the high biotin levels in cell cultures are necessary.
5.3. Vitamin B9. Folate depletion appears to enhance carcinogenesis, whereas folate supplementation above what is presently considered to be the basal requirement confers a protective effect [180]. A few examples of folate deficiency and supplementation are described in Table 3, and the relationship between this vitamin and cell proliferation and apoptosis has been demonstrated. Furthermore, as can be verified in Table 2, the folate levels in the cell-culture media evaluated are typically higher than those levels found in human serum. It is well established that folate deficiency can influence the genomic stability of cultured cells [81, 181], yet there is still a lack of data evaluating whether folate levels above the physiological range can impair cell growth. Elevated levels of folic acid should be examined, as in tumor-prone animals, both folate deficiency and supplementation promote the progression of established neoplasms $[83,182]$. As a folate overload is more common than a deficiency in in vitro studies, the former should be most thoroughly evaluated.

5.4. Vitamin B12. Vitamin B12 deficiency has been described as similar to chemicals that damage DNA by causing singleand double-strand breaks [20]. As demonstrated in Table 3, in a cellular model designed to better understand vitamin B12 deficiency in the brain, the growth and differentiation of neuronal cells were affected [89]. Additionally, supplementation with certain cobalamin compounds protected the cells from neurotoxicity and increased cell growth [170, 171]. Unfortunately, in vitro research demonstrating a direct link between vitamin B12 deficiency or overload and genomic stability in human cells has not yet been published. Based on Table 2, however, high concentrations of vitamin B12 are more common in cell-culture media than in human serum.

5.5. Vitamin C. In Table 3, a few examples of the influence of vitamin $C$ in cell cultures are provided. Different concentrations of this vitamin result in distinct responses, ranging from DNA damage (at higher concentrations) to the protection of DNA (at lower concentrations). Importantly, the concentration of vitamin $\mathrm{C}$ in current cell cultures is not available in Table 2, as possibly only trace levels are present in media. As the cellular response to vitamin $\mathrm{C}$ may be dosedependent, a similar concentration of this vitamin in culture media to that in human serum should be evaluated.

5.6. Vitamin E. In vivo vitamin E supplementation is still being discussed [183], and more in vitro studies will be required to better understand the protective effects of vitamin E on cell viability and genomic stability. Nevertheless, certain results (Table 3) have been consistent with the concept that $\alpha$ tocopherol, combined with ascorbic acid or alone, can protect against oxidative DNA damage [175] and reduce apoptosis and autophagy [177] under certain conditions. Unfortunately, the current in vitro concentration of vitamin $\mathrm{E}$ is also not available in Table 2, as possibly only trace levels are present in media. Given this observation, it is interesting to observe that the in vitro studies of vitamin $\mathrm{E}$ described in Table 3 adopted concentration values similar to that of human serum (approximately $30 \mu \mathrm{mol} / \mathrm{L}$ ) and that the results were positive for the cell cultures. 


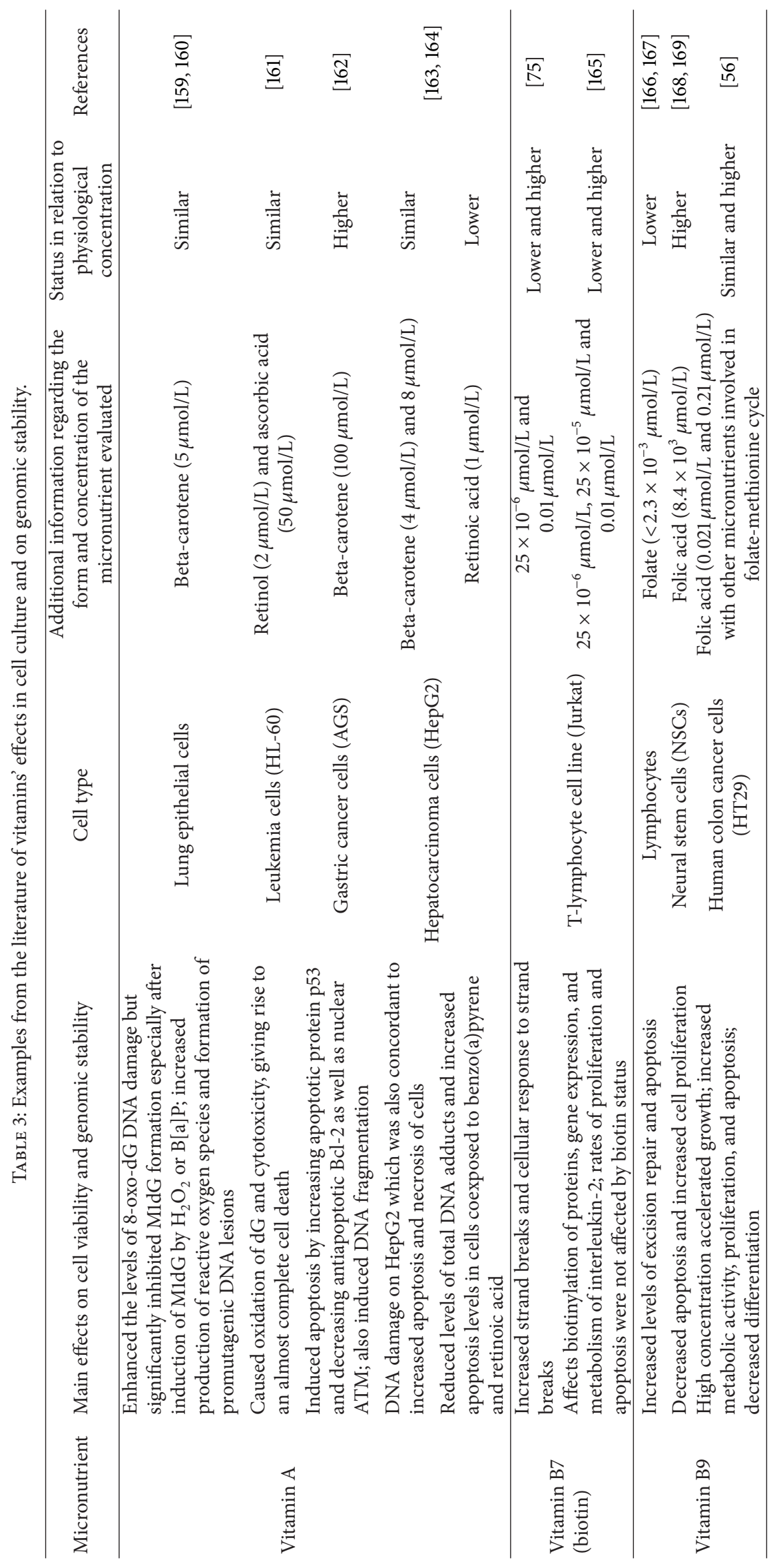




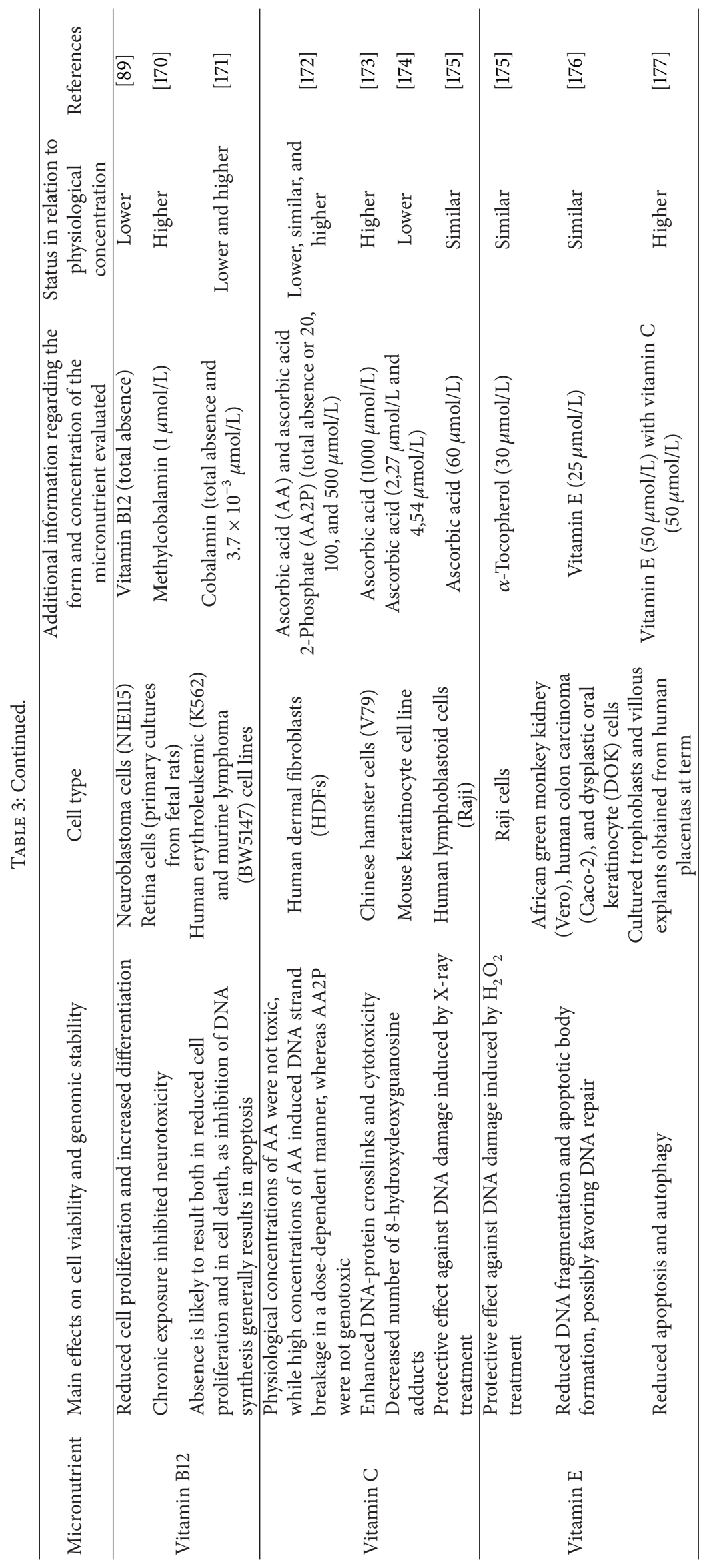


5.7. Copper. As can be verified in Table 2, there is a marked lack of copper in common cell-culture media, even when supplemented with FBS. Thus, cells in culture are typically exposed to an environment deficient in a micronutrient critical for the formation of detoxifying enzymes, which may impact cell development and possibly genomic stability and survival rates. It is important to note that the copper concentrations evaluated in cell culture (Table 4) are generally above the human physiological range, so toxic effects in cultures should be expected. Thus, the optimization of the copper concentration in cell cultures is necessary to maintain cell viability and genomic stability and to avoid the deleterious effects of this metal.

5.8. Iron. In Table 4, it is important to note that the results of Lima et al. [187] may be expected in a cell culture in which the requirements for micronutrients are quite different from those in vivo. In this study, the concentrations evaluated were generally higher than the values measured in human serum (Table 2), and even the lowest concentration of iron applied for the authors $(22.38 \mu \mathrm{mol} / \mathrm{L})$ would be considered high for cells in culture. For HL-60 leukemia cells, as demonstrated in [201], the iron concentration range for optimal cell proliferation is very narrow $(2-3 \mu \mathrm{mol} / \mathrm{L})$. In contrast, in the studies in which the iron levels were between 5 and $10 \mu \mathrm{mol} / \mathrm{L}$, these levels generally benefitted the cultures analyzed, or at least no damage was observed [187-189].

5.9. Magnesium. As presented in Table 4, several studies on the effects of magnesium deficiency on cultured cells have demonstrated reduced oxidative stress, cell-cycle progression, cell growth, and cell viability [190, 191, 202-207]. Killilea and Ames [192] specifically investigated the consequences of long-term and moderate magnesium deficiency in normal human cells in comparison with more typical magnesium levels, using a concentration observed in normal human serum $(0.8 \mathrm{mmol} / \mathrm{L})$. No alterations were observed in the cells cultured in the medium containing normal magnesium levels. Additionally, based on studies conducted either in bacteria or in mammalian cells in culture, there is no evidence for the genotoxic effects of magnesium salts at physiologically relevant doses [29], indicating that adequate micronutrient levels in cell-culture media may improve cell viability and genomic stability. As shown in Table 2, the levels of magnesium currently found in cell-culture media are very similar to those levels in human serum, which is very unusual for micronutrients in general.

5.10. Selenium. The differential toxicities elicited by selenocompounds need to be taken into account in in vivo and in vitro supplementation studies [194]. The references in Table 4 evaluated different forms of selenium and certain salts that may be more toxic to the cellular environment than others. Due to the importance of selenium as well as many other micronutrients discussed in this review, the micronutrient concentration in the media, as well as the FBS, intended for cell culture should be controlled and adjusted to the physiological range, if applicable. By comparing the human serum concentration of selenium in Table 2 with those concentrations described in the experiments cited in Table 4, it is apparent that the concentrations below the physiological range benefitted the cell culture, although high concentrations of selenium compounds potentially negatively affected tumor cells.

5.11. Zinc. The role of zinc in genomic stability was recently reviewed by Sharif et al. [208]. Additionally, a few brief examples of zinc's influence on cell viability and genomic stability are provided in Table 4 . A possible conclusion from the in vitro assays is that when the zinc concentration used is below the human serum value (Table 2 ), the results tend to be beneficial for the cultured cells. In contrast, zinc concentrations above the physiological level can damage cultured cells. Again, it is interesting to observe that certain cell-culture media (e.g., HAM F-10 and F-12), even when supplemented with FBS, cannot provide enough of this micronutrient for appropriate cell development and genomic stability once the concentration falls below the physiological range.

\section{What Must Be Done: Limitations of the Available Evidence and Conclusions}

Micronutrients are clearly important for cell development and genomic stability, and many of the micronutrients mentioned are necessary for the DNA synthesis and repair mechanisms. Table 5 provides an overview of the current data regarding the effects of deficiencies or excesses of the micronutrients addressed in this review on genomic stability. The micronutrient levels found in the discussed cell-culture media and the status of research on each micronutrient are also highlighted. Evidently, much research has been performed, but more specific studies focusing on cell cultures are still required.

Even though there are some highly enriched media available as basal media for serum-free cell culture, like Medium 199 or Ham F-12 nutrient mixture, the most common source of micronutrients currently used in cell cultures is still FBS. The limitations of FBS in providing adequate micronutrient concentrations have been analyzed and described in the literature [34]. Given that cell- and tissue-culture models are generally important in scientific research, the development of standards in vitro methods is mandatory. These new standards will decrease dependence on animal serum, a supplement with an undefined, variable composition that can considerably influence experimental results [209]. Furthermore, according to van der Valk et al. [209], an improved exchange of information regarding newly developed serumfree media may be beneficial. It has also become clear that nearly every cell type has distinct requirements for media supplementation, and especially, as discussed in this review, for micronutrient supplementation. A universal cell- and tissue-culture medium may not be feasible, as different cell types have different receptors involved in cell survival, growth and differentiation, and release different factors into the surrounding environment.

Besides this, it is important to highlight that although the formulations of the classical cell culture media are unchanged for a long time, since their development, the quality and 


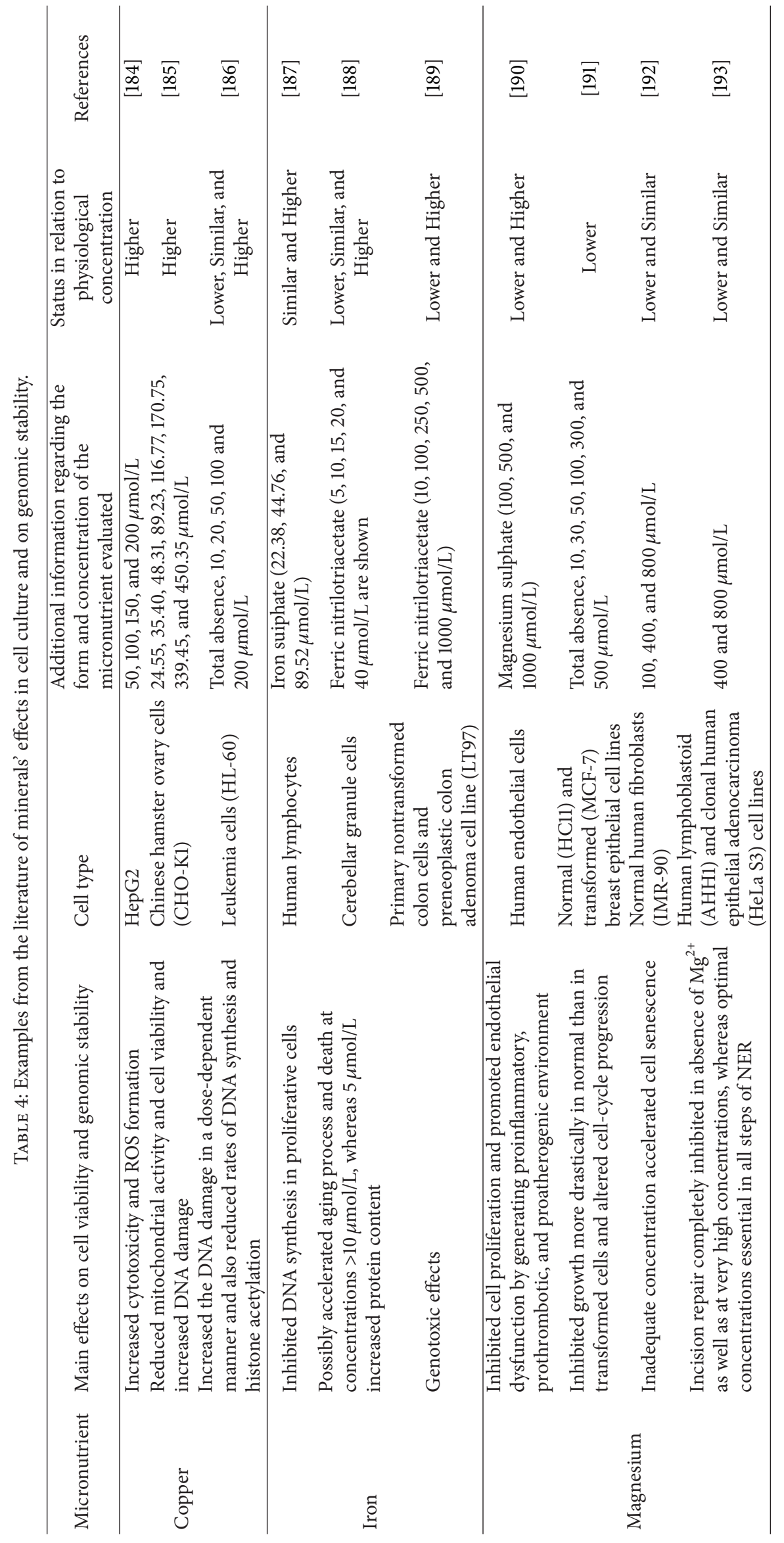




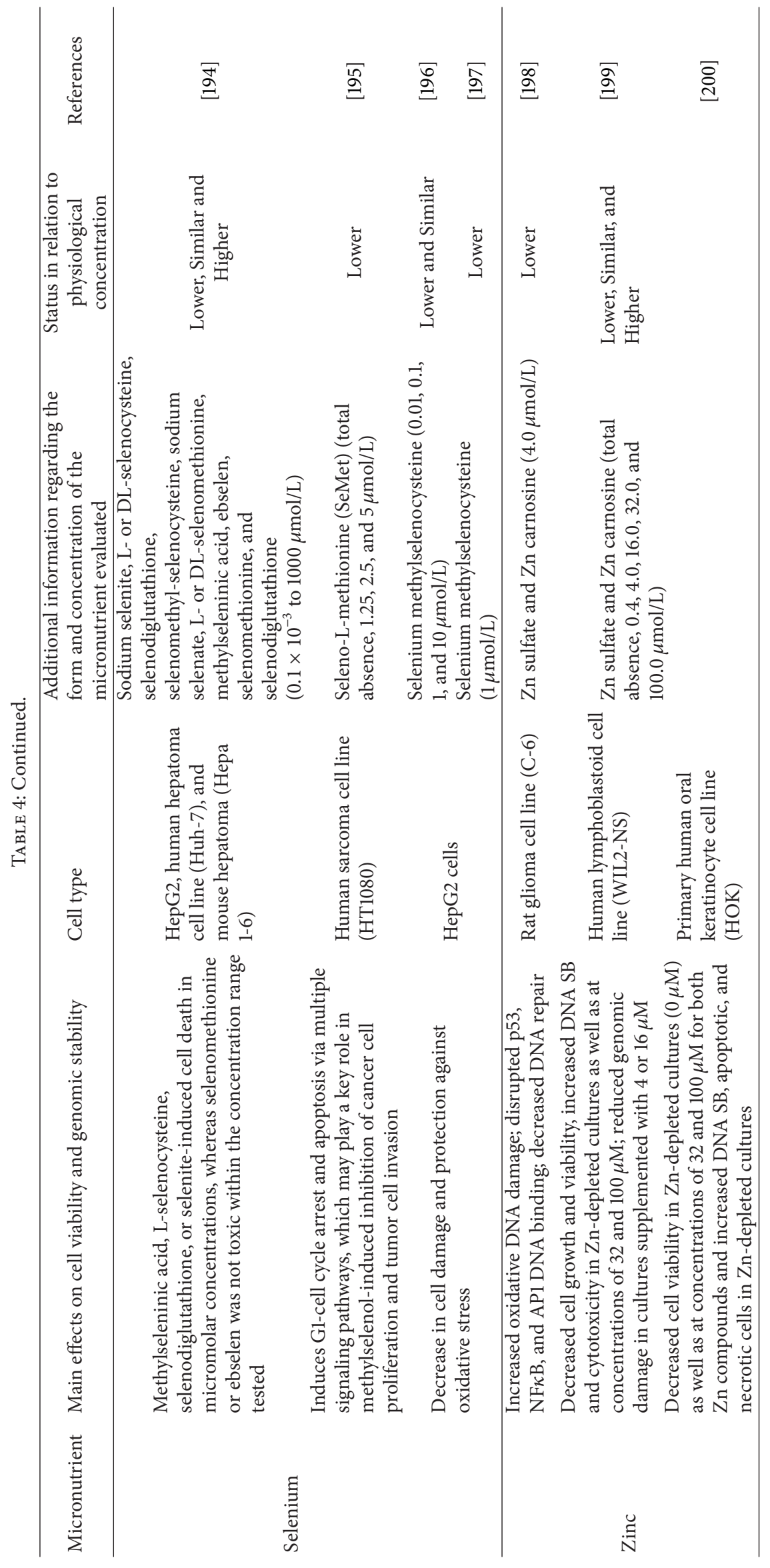


TABLE 5: Overview of the data addressed in this review.

\begin{tabular}{lcccc}
\hline Micronutrient & \multicolumn{2}{c}{$\begin{array}{c}\text { Evidence of genomic instability induction } \\
\text { Deficiency }\end{array}$} & $\begin{array}{c}\text { Concess } \\
\text { media versus physiological concentration }\end{array}$ & $\begin{array}{c}\text { Optimal concentration } \\
\text { proposed for cell culture }\end{array}$ \\
\hline Vitamin A & + & + & Lower & Studied \\
Vitamin B7 & + & + & Higher & Requires more studies \\
Vitamin B9 & + & + & Higher & Studied \\
Vitamin B12 & + & NA & Higher & Studied \\
Vitamin C & + & + & Unknown & Studied \\
Vitamin E & - & + & Unknown & Studied \\
Copper & + & + & Lower & Studied \\
Iron & + & + & Lower & Studied \\
Magnesium & NA & + & Similar & Studied \\
Selenium & + & - & Lower & Studied \\
Zinc & + & + & Lower & Studied \\
\hline
\end{tabular}

NA: Not available.

(-) Negative: the available data indicate no effect.

(+) Positive: the available data indicate an effect.

purity of single components used as supplements, are likely to have increased considerably. However, some losses of important substances could have occurred, including trace elements, vitamins, growth factors, and lipids and this should be better addressed before defined a serum-free media. In fact, the threshold for developing and using a new welldefined medium, given that the current FBS-supplemented culture media work well, is high [209]. At the very least, an evaluation of FBS composition, in terms of micronutrients and possibly other factors, should be strongly considered in the laboratories that focus on in vitro studies. Knowledge of the micronutrient composition of FBS may help to minimize the bias in experimental results. However, maintaining both successful and consistent cell cultures can be difficult, as FBS is a complex natural product and may vary between batches, even if obtained from a single manufacturer. More specifically, the quality and concentration of both bulk and specific proteins in cell cultures can affect cell growth [210]. Adjusting the in vitro micronutrient levels to physiological values will guarantee a better environment for cell development, mimicking the in vivo milieu.

Further studies on the effects of micronutrients on cell viability, proliferation, and stability, as well as gene expression and integrity are still required, but the information already available is a sufficient call to action. As mentioned by Ferguson and Fenech [141], most investigations have been limited to studying the effects of single micronutrients and have not considered genetic consequences. Thus, there is an important need for studies that also examine nutrientnutrient and nutrient-gene interactions. Determining the physiological range of such significant micronutrients as iron and then adjusting the concentrations currently found in cellculture media may be beneficial for in vitro assays. More specifically, the viability and genomic stability of cell lines and primary cultures may be improved. Depending on the cell type (primary, immortalized, tumor, or normal) and origin (lung, hepatic, neural, or other), the requirement for a micronutrient may vary widely, so this subject should be carefully evaluated. Finally, the form of the micronutrient used in supplementation media may also influence experimental results. For example, according to Jacobs et al. [211], whether iron has toxic effects is directly related to the presence of a chelating agent, which reduces the concentration of free ferric ion and promotes the formation of ferritin.

Once the relationship between an in vivo imbalance of micronutrients and genomic stability, which may cause many diseases, including cancer, is established, it will be mandatory to better understand in vitro micronutrient supplementation. In fact, certain simple questions, such as "is the concentration of this micronutrient sufficient for the development of this cell?" or "are the levels of this micronutrient similar to the levels observed in human serum?", may aid the proper design of in vitro studies.

\section{Acknowledgment}

The authors are grateful for funding from PRONEX/ FAPERGS/CNPq (Project no. 10/0044-3).

\section{References}

[1] "Iron deficiency. Are you getting enough of this essential mineral?" Mayo Clinic Women's Healthsource, vol. 3, no. 1, p. 6, 1999.

[2] D. Pra, A. Bortoluzzi, L. L. Müller et al., "Iron intake, red cell indicators of iron status, and DNA damage in young subjects," Nutrition, vol. 27, no. 3, pp. 293-297, 2011.

[3] D. Pra, S. I. Rech Franke, J. A. Pegas Henriques, and M. Fenech, "A possible link between iron deficiency and gastrointestinal carcinogenesis," Nutrition and Cancer, vol. 61, no. 4, pp. 415426, 2009.

[4] M. Fenech, "The role of folic acid and Vitamin B12 in genomic stability of human cells," Mutation Research, vol. 475, no. 1-2, pp. 57-67, 2001. 
[5] M. Fenech, C. Aitken, and J. Rinaldi, "Folate, vitamin B12, homocysteine status and DNA damage in young Australian adults," Carcinogenesis, vol. 19, no. 7, pp. 1163-1171, 1998.

[6] J. Salas, I. Font, J. Canals, J. Fernández, and C. MartíHenneberg, "Consumption, food habits and nutritional status of the Reus population: VI. Risk of micronutrient malnutrition," Medicina Clinica, vol. 88, no. 10, pp. 405-410, 1987.

[7] C. S. Yang and H. L. Newmark, "The role of micronutrient deficiency in carcinogenesis," Critical Reviews in Oncology/Hematology, vol. 7, no. 4, pp. 267-287, 1987.

[8] R. M. Russell, "Micronutrient requirements of the elderly," Nutrition Reviews, vol. 50, no. 12, pp. 463-466, 1992.

[9] L. H. Allen, "Maternal micronutrient malnutrition: effects on breast milk and infant nutrition, and priorities for intervention," SCN News, no. 11, pp. 21-24, 1994.

[10] S. Mobarhan, "Micronutrient supplementation trials and the reduction of cancer and cerebrovascular incidence and mortality," Nutrition Reviews, vol. 52, no. 3, pp. 102-105, 1994.

[11] S. Southon, A. J. A. Wright, P. M. Finglas, A. L. Bailey, J. M. Loughridge, and A. D. Walker, "Dietary intake and micronutrient status of adolescents: effect of vitamin and trace element supplementation on indices of status and performance in tests of verbal and non-verbal intelligence," British Journal of Nutrition, vol. 71, no. 6, pp. 897-918, 1994.

[12] "Know how: vitamins and minerals. Part 5. Key micronutrient requirements during adolescence 11-18 years," Nursing Times, vol. 93, no. 34, pp. 72-73, 1997.

[13] B. N. Ames, "DNA damage from micronutrient deficiencies is likely to be a major cause of cancer," Mutation Research, vol. 475, no. 1-2, pp. 7-20, 2001.

[14] M. C. Latham, D. Ash, G. Ndossi, H. Mehansho, and S. Tatala, "Micronutrient dietary supplements-a new fourth approach," Archivos Latinoamericanos de Nutricion, vol. 51, no. 1, pp. 37-41, 2001.

[15] K. A. Bartley, B. A. Underwood, and R. J. Deckelbaum, "A life cycle micronutrient perspective for women's health," American Journal of Clinical Nutrition, vol. 81, supplement 5, pp. 1188S1193S, 2005.

[16] B. A. Haider and Z. A. Bhutta, "Multiple-micronutrient supplementation for women during pregnancy," Cochrane Database of Systematic Reviews, no. 4, p. CD004905, 2006.

[17] I. Thorsdottir and B. S. Gunnarsson, "Dietary quality and adequacy of micronutrient intakes in children," Proceedings of the Nutrition Society, vol. 65, no. 4, pp. 366-375, 2006.

[18] K. Sriram and V. A. Lonchyna, "Micronutrient supplementation in adult nutrition therapy: practical considerations," Journal of Parenteral and Enteral Nutrition, vol. 33, no. 5, pp. 548-562, 2009.

[19] L. M. Neufeld and B. M. Cameron, "Identifying nutritional need for multiple micronutrient interventions," Journal of Nutrition, vol. 142, supplement 1, pp. 166S-172S, 2012.

[20] B. N. Ames, "Micronutrient deficiencies. A major cause of DNA damage," Annals of the New York Academy of Sciences, vol. 889, pp. 87-106, 1999.

[21] D. Pra, S. I. Rech Franke, J. A. Henriques, and M. Fenech, "Iron and genome stability: an update," Mutation Research, vol. 733, no. 1-2, pp. 92-99, 2012.

[22] S. Friso and S. W. Choi, "Gene-nutrient interactions and DNA methylation," Journal of Nutrition, vol. 132, supplement 8, pp. 2382S-2387S, 2002.
[23] M. Fenech and L. R. Ferguson, "Vitamins/minerals and genomic stability in humans," Mutation Research, vol. 475, no. 1-2, pp. $1-6,2001$.

[24] M. Fenech and L. R. Ferguson, "Vitamins/minerals and genomic stability in humans," Mutation Research, vol. 475, no. 1-2, pp. $1-6,2001$.

[25] B. N. Ames, "DNA damage from micronutrient deficiencies is likely to be a major cause of cancer," Mutation Research, vol. 475, no. 1-2, pp. 7-20, 2001.

[26] B. Halliwell, "Vitamin C and genomic stability," Mutation Research, vol. 475, no. 1-2, pp. 29-35, 2001.

[27] K. J. Claycombe and S. N. Meydani, "Vitamin E and genome stability," Mutation Research, vol. 475, no. 1-2, pp. 37-44, 2001.

[28] M. Chatterjee, "Vitamin D and genomic stability," Mutation Research, vol. 475, no. 1-2, pp. 69-88, 2001.

[29] A. Hartwig, "Role of magnesium in genomic stability," Mutation Research, vol. 475, no. 1-2, pp. 113-121, 2001.

[30] J. M. De Freitas and R. Meneghini, "Iron and its sensitive balance in the cell," Mutation Research, vol. 475, no. 1-2, pp. 153-159, 2001.

[31] A. R. Collins, "Carotenoids and genomic stability," Mutation Research, vol. 475, no. 1-2, pp. 21-28, 2001.

[32] Z. Wang, A. M. Joshi, K. Ohnaka et al., "Dietary intakes of retinol, carotenes, vitamin $\mathrm{C}$, and vitamin $\mathrm{E}$ and colorectal cancer risk: the Fukuoka colorectal cancer study," Nutrition and Cancer, vol. 64, no. 6, pp. 798-805, 2012.

[33] S. R. Rana, N. Colman, and Kong OO Goh, “Transcobalamin II deficiency associated with unusual bone marrow findings and chromosomal abnormalities," American Journal of Hematology, vol. 14, no. 1, pp. 89-96, 1983.

[34] N. Bryan, K. D. Andrews, M. J. Loughran, N. P. Rhodes, and J. A. Hunt, "Elucidating the contribution of the elemental composition of fetal calf serum to antigenic expression of primary human umbilical-vein endothelial cells in vitro," Bioscience Reports, vol. 31, no. 3, pp. 199-210, 2011.

[35] H. Hennings, D. Michael, and C. Cheng, "Calcium regulation of growth and differentiation of mouse epidermal cells in culture," Cell, vol. 19, no. 1, pp. 245-254, 1980.

[36] X. M. Zhang, G. W. Huang, Z. H. Tian, D. L. Ren, and J. $\mathrm{X}$. Wilson, "Folate stimulates ERK1/2 phosphorylation and cell proliferation in fetal neural stem cells," Nutritional Neuroscience, vol. 12, no. 5, pp. 226-232, 2009.

[37] N. E. L. Saris, E. Mervaala, H. Karppanen, J. A. Khawaja, and A. Lewenstam, "Magnesium: an update on physiological, clinical and analytical aspects," Clinica Chimica Acta, vol. 294, no. 1-2, pp. 1-26, 2000.

[38] D. H. Boldt, "New perspectives on iron: an introduction," American Journal of the Medical Sciences, vol. 318, no. 4, pp. 207$212,1999$.

[39] S. Friso and S. W. Choi, "Gene-nutrient interactions and DNA methylation," Journal of Nutrition, vol. 132, supplement 8, pp. 2382S-2387S, 2002.

[40] L. R. Ferguson and M. Philpott, "Nutrition and mutagenesis," Annual Review of Nutrition, vol. 28, pp. 313-329, 2008.

[41] D. Hanahan and R. A. Weinberg, "The hallmarks of cancer," Cell, vol. 100, no. 1, pp. 57-70, 2000.

[42] T. Sjöblom, S. Jones, L. D. Wood et al., "The consensus coding sequences of human breast and colorectal cancers," Science, vol. 314, no. 5797, pp. 268-274, 2006.

[43] B. N. Ames, "Micronutrients prevent cancer and delay aging," Toxicology Letters, vol. 102-103, pp. 5-18, 1998. 
[44] M. Fenech, "Micronutrients and genomic stability: a new paradigm for recommended dietary allowances (RDAs)," Food and Chemical Toxicology, vol. 40, no. 8, pp. 1113-1117, 2002.

[45] A. C. Boyonoski, L. M. Gallacher, M. M. ApSimon et al., "Niacin deficiency increases the sensitivity of rats to the short and long term effects of ethylnitrosourea treatment," Molecular and Cellular Biochemistry, vol. 193, no. 1-2, pp. 83-87, 1999.

[46] E. L. Jacobson, W. M. Shieh, and A. C. Huang, "Mapping the role of NAD metabolism in prevention and treatment of carcinogenesis," Molecular and Cellular Biochemistry, vol. 193, no. 1-2, pp. 69-74, 1999.

[47] C. M. Simbulan-Rosenthal, B. R. Haddad, D. S. Rosenthal et al., "Chromosomal aberrations in $\mathrm{PARP}^{-/-}$mice: genome stabilization in immortalized cells by reintroduction of poly(ADPribose) polymerase cDNA," Proceedings of the National Academy of Sciences of the United States of America, vol. 96, no. 23, pp. 13191-13196, 1999.

[48] C. Bolognesi, E. Ognio, L. Ferreri-Santi, and L. Rossi, "Modulation of DNA damage by vitamin A in developing SpragueDawley rats," Anticancer Research, vol. 12, no. 5, pp. 1587-1591, 1992.

[49] Institute of Medicine (IOM), Dietary Reference Intakes For Vitamin C, Vitamin E, Selenium, and Carotenoids. Food and Nutrition Board, National Academy Press, Washington, DC, USA, 2000.

[50] F. Klamt, F. Dal-Pizzol, R. Roehrs et al., "Genotoxicity, recombinogenicity and cellular preneoplasic transformation induced by Vitamin A supplementation," Mutation Research, vol. 539, no. 1-2, pp. 117-125, 2003.

[51] Institute of Medicine (IOM), Dietary Reference Intakes For Dietary Reference Intakes For Thiamin, Riboflavin, Niacin, Vitamin B6, Folate, Vitamin B12, Pantothenic Acid, Biotin, and Choline. Food and Nutrition Board, National Academy Press, Washington, DC, USA, 1998.

[52] J. Zempleni, D. C. Teixeira, T. Kuroishi, E. L. Cordonier, and S. Baier, "Biotin requirements for DNA damage prevention," $M u$ tation Research, vol. 733, no. 1-2, pp. 58-60, 2012.

[53] M. Fenech, P. Baghurst, W. Luderer et al., "Low intake of calcium, folate, nicotinic acid, vitamin $\mathrm{E}$, retinol, $\beta$-carotene and high intake of pantothenic acid, biotin and riboflavin are significantly associated with increased genome instabilityresults from a dietary intake and micronucleus index survey in South Australia," Carcinogenesis, vol. 26, no. 5, pp. 991-999, 2005.

[54] A. Báez-Saldaña, I. Camacho-Arroyo, J. J. Espinosa-Aguirre et al., "Biotin deficiency and biotin excess: effects on the female reproductive system," Steroids, vol. 74, no. 10-11, pp. 863-869, 2009.

[55] M. Kliemann, D. Pra, L. L. Muller et al., "DNA damage in children and adolescents with cardiovascular disease risk factors," Anais da Academia Brasileira de Ciências, vol. 84, no. 3, pp. 833-840, 2012.

[56] L. Pellis, Y. Dommels, D. Venema et al., "High folic acid increases cell turnover and lowers differentiation and iron content in human HT29 colon cancer cells," British Journal of Nutrition, vol. 99, no. 4, pp. 703-708, 2008.

[57] I. D. Podmore, H. R. Griffiths, K. E. Herbert, N. Mistry, P. Mistry, and J. Lunec, "Vitamin C exhibits pro-oxidant properties," Nature, vol. 392, no. 6676, p. 559, 1998.

[58] C. Constantinou, C. M. Neophytou, P. Vraka, J. A. Hyatt, K. A. Papas, and A. I. Constantinou, "Induction of DNA damage and caspase-independent programmed cell death by vitamin E," Nutrition and Cancer, vol. 64, no. 1, pp. 136-152, 2012.

[59] S. N. Hawk, L. Lanoue, C. L. Keen, C. L. Kwik-Uribe, R. B. Rucker, and J. Y. Uriu-Adams, "Copper-deficient rat embryos are characterized by low superoxide dismutase activity and elevated superoxide anions," Biology of Reproduction, vol. 68, no. 3, pp. 896-903, 2003.

[60] Institute of Medicine (IOM), Dietary Reference Intakes for Vitamin A, Vitamin K, Arsenic, Boron, Chromium, Copper, Iodine, Iron, Molybdenum, Nickel, Sillicon, Vanadium and Zinc. Food and Nutrition Board, National Academy Press, Washington, DC, USA, 2001.

[61] A. Hartwig, "Role of magnesium in genomic stability," Mutation Research, vol. 475, no. 1-2, pp. 113-121, 2001.

[62] Institute of Medicine (IOM), Dietary Reference Intakes for Dietary Reference Intakes for Calcium, Phosphorus, Magnesium, Vitamin D, and Fluoride. Food and Nutrition Board, National Academy Press, Washington, DC, USA, 1997.

[63] E. C. Chiang, S. Shen, S. S. Kengeri et al., "Defining the optimal selenium dose for prostate cancer risk reduction: insights from the u-shaped relationship between selenium status, DNA damage, and apoptosis," Dose-Response, vol. 8, no. 3, pp. 285$300,2010$.

[64] U. Harréus, P. Baumeister, S. Zieger, and C. Matthias, "The influence of high doses of vitamin C and zinc on oxidative DNA damage," Anticancer Research, vol. 25, no. 5, pp. 3197-3201, 2005.

[65] A. Azqueta and A. R. Collins, "Carotenoids and DNA damage," Mutation Research, vol. 733, no. 1-2, pp. 4-13, 2012.

[66] R. Roehrs, D. R. J. Freitas, A. Masuda et al., "Effect of vitamin A treatment on superoxide dismutase-deficient yeast strains," Archives of Microbiology, vol. 192, no. 3, pp. 221-228, 2010.

[67] L. M. Lee, C. Y. Leung, W. W. Tang et al., "A paradoxical teratogenic mechanism for retinoic acid," Proceedings of the National Academy of Sciences of the United States of America, vol. 109, no. 34, pp. 13668-13673, 2012.

[68] M. F. Donald and S. McLaren, "Sight and life manual on vitamin A deficiency disorders (VADD)," in Task Force Sight and Life, T. F. S. A. LIFE, Ed., 2001.

[69] A. Sommer and K. S. Vyas, "A global clinical view on vitamin A and carotenoids," American Journal of Clinical Nutrition, vol. 96, supplement 5, pp. 1204S-1206S, 2012.

[70] L. Mayende, R. D. Swift, L. M. Bailey et al., "A novel molecular mechanism to explain biotin-unresponsive holocarboxylase synthetase deficiency," Journal of Molecular Medicine, vol. 90, no. 1, pp. 81-88, 2012.

[71] S. Jitrapakdee and J. C. Wallace, "The biotin enzyme family: conserved structural motifs and domain rearrangements," Current Protein and Peptide Science, vol. 4, no. 3, pp. 217-229, 2003.

[72] M. Saunders, L. Sweetman, and B. Robinson, "Biotin-response organicaciduria. Multiple carboxylase defects and complementation studies with propionicacidemia in cultured fibroblasts," Journal of Clinical Investigation, vol. 64, no. 6, pp. 1695-1702, 1979.

[73] B. Wolf and G. L. Feldman, "The biotin-dependent carboxylase deficiencies," American Journal of Human Genetics, vol. 34, no. 5, pp. 699-716, 1982.

[74] C. J. Wilson, M. Myer, B. A. Darlow et al., "Severe holocarboxylase synthetase deficiency with incomplete biotin responsiveness resulting in antenatal insult in Samoan neonates," Journal of Pediatrics, vol. 147, no. 1, pp. 115-118, 2005. 
[75] R. Rodriguez-Melendez, J. B. Griffin, and J. Zempleni, "Biotin supplementation increases expression of the cytochrome P 450 1B1 gene in Jurkat cells, increasing the occurrence of singlestranded DNA breaks," Journal of Nutrition, vol. 134, no. 9, pp. 2222-2228, 2004.

[76] T. Watanabe, Y. Nagai, A. Taniguchi, S. Ebara, S. Kimura, and T. Fukui, "Effects of biotin deficiency on embryonic development in mice," Nutrition, vol. 25, no. 1, pp. 78-84, 2009.

[77] K. Dakshinamurti and J. Chauhan, "Biotin," Vitamins and Hormones C, vol. 45, pp. 337-384, 1989.

[78] B. C. Blount, M. M. Mack, C. M. Wehr et al., "Medical sciences folate deficiency causes uracil misincorporation into human DNA and chromosome breakage: implications for cancer and neuronal damage," Proceedings of the National Academy of Sciences of the United States of America, vol. 94, no. 7, pp. 32903295, 1997.

[79] B. C. Blount and B. N. Ames, "DNA damage in folate deficiency," Bailliere's Clinical Haematology, vol. 8, no. 3, pp. 461-478, 1995.

[80] T. Lindahl and R. D. Wood, "Quality control by DNA repair," Science, vol. 286, no. 5446, pp. 1897-1905, 1999.

[81] G. M. Li, S. R. Presnell, and L. Gu, "Folate deficiency, mismatch repair-dependent apoptosis, and human disease," Journal of Nutritional Biochemistry, vol. 14, no. 10, pp. 568-575, 2003.

[82] N. Pancharuniti, C. A. Lewis, H. E. Sauberlich et al., "Plasma homocyst(e)ine, folate, and vitamin B-12 concentrations and risk for early-onset coronary artery disease," American Journal of Clinical Nutrition, vol. 59, no. 4, pp. 940-948, 1994.

[83] Y. I. Kim, "Folate, colorectal carcinogenesis, and DNA methylation: lessons from animal studies," Environmental and Molecular Mutagenesis, vol. 44, no. 1, pp. 10-25, 2004.

[84] J. Chen, E. Giovannucci, K. Kelsey et al., "A methylenetetrahydrofolate reductase polymorphism and the risk of colorectal cancer," Cancer Research, vol. 56, no. 21, pp. 4862-4864, 1996.

[85] J. Ma, M. J. Stampfer, E. Giovannucci et al., "Methylenetetrahydrofolate reductase polymorsphism, dietary interactions, and risk of colorectal cancer," Cancer Research, vol. 57, no. 6, pp. 1098-1102, 1997.

[86] E. Giovannucci, M. J. Stampfer, G. A. Colditz et al., "Multivitamin use, folate, and colon cancer in women in the nurses' health study," Annals of Internal Medicine, vol. 129, no. 7, pp. 517-524, 1998.

[87] S. Zhang, D. J. Hunter, S. E. Hankinson et al., "A prospective study of folate intake and the risk of breast cancer," Journal of the American Medical Association, vol. 281, no. 17, pp. 1632-1637, 1999.

[88] J. M. Salbaum and C. Kappen, "Genetic and epigenomic footprints of folate," Progress in Molecular Biology and Translational Science, vol. 108, pp. 129-158, 2012.

[89] S. F. Battaglia-Hsu, N. Akchiche, N. Noel et al., "Vitamin B12 deficiency reduces proliferation and promotes differentiation of neuroblastoma cells and up-regulates PP2A, proNGF, and TACE," Proceedings of the National Academy of Sciences of the United States of America, vol. 106, no. 51, pp. 21930-21935, 2009.

[90] M. S. Morris, "The role of B vitamins in preventing and treating cognitive impairment and decline," Advances in Nutrition, vol. 3, no. 6, pp. 801-812, 2012.

[91] J. M. Zingg and P. A. Jones, "Genetic and epigenetic aspects of DNA methylation on genome expression, evolution, mutation and carcinogenesis," Carcinogenesis, vol. 18, no. 5, pp. 869-882, 1997.
[92] T. Sanz-Cuesta, P. Gonzalez-Escobar, R. Riesgo-Fuertes et al., "Oral versus intramuscular administration of vitamin B12 for the treatment of patients with vitamin B12 deficiency: a pragmatic, randomised, multicentre, non-inferiority clinical trial undertaken in the primary healthcare setting (Project OB12)'”, BMC Public Health, vol. 12, p. 394, 2012.

[93] D. L. Smith, "Anemia in the elderly," American Family Physician, vol. 62, no. 7, pp. 1565-1572, 2000.

[94] M. G. Traber and J. F. Stevens, "Vitamins C and E: beneficial effects from a mechanistic perspective," Free Radical Biology and Medicine, vol. 51, no. 5, pp. 1000-1013, 2011.

[95] P. H. Gann, "Randomized trials of antioxidant supplementation for cancer prevention: first bias, now chance-next, cause," Journal of the American Medical Association, vol. 301, no. 1, pp. 102-103, 2009.

[96] J. M. Gaziano, R. J. Glynn, W. G. Christen et al., "Vitamins E and $\mathrm{C}$ in the prevention of prostate and total cancer in men: the physicians' health study II randomized controlled trial," Journal of the American Medical Association, vol. 301, no. 1, pp. 52-62, 2009.

[97] S. J. Padayatty, A. Y. Sun, Q. Chen, M. G. Espey, J. Drisko, and M. Levine, "Vitamin C: intravenous use by complementary and alternative medicine practitioners and adverse effects," PLoS One, vol. 5, no. 7, Article ID e11414, 2010.

[98] J. X. Wilson, "Mechanism of action of vitamin C in sepsis: ascorbate modulates redox signaling in endothelium," BioFactors, vol. 35, no. 1, pp. 5-13, 2009.

[99] G. L. Bowman, H. Dodge, B. Frei et al., "Ascorbic acid and rates of cognitive decline in Alzheimer's disease," Journal of Alzheimer's Disease, vol. 16, no. 1, pp. 93-98, 2009.

[100] R. D. Ravindran, P. Vashist, S. K. Gupta et al., "Prevalence and risk factors for vitamin $\mathrm{C}$ deficiency in north and south India: a two centre population based study in people aged 60 years and over," PLoS One, vol. 6, no. 12, Article ID e28588, 2011.

[101] M. G. Traber and J. Atkinson, "Vitamin E, antioxidant and nothing more," Free Radical Biology and Medicine, vol. 43, no. 1, pp. 4-15, 2007.

[102] Y. Ni and C. Eng, "Vitamin E protects against lipid peroxidation and rescues tumorigenic phenotypes in cowden/cowden-like patient-derived lymphoblast cells with germline SDHx variants," Clinical Cancer Research, vol. 18, no. 18, pp. 4954-4961, 2012.

[103] T. Bergstrom, C. Ersson, J. Bergman, and L. Moller, "Vitamins at physiological levels cause oxidation to the DNA nucleoside deoxyguanosine and to DNA-alone or in synergism with metals," Mutagenesis, vol. 27, no. 4, pp. 511-517, 2012.

[104] D. K. Dror and L. H. Allen, "Vitamin e deficiency in developing countries," Food and Nutrition Bulletin, vol. 32, no. 2, pp. 124143, 2011.

[105] M. C. Linder, "The relationship of copper to DNA damage and damage prevention in humans," Mutation Research, vol. 733, no. 1-2, pp. 83-91, 2012.

[106] J. F. Collins and L. M. Klevay, "Copper," Advances in Nutrition, vol. 2, no. 6, pp. 520-522, 2011.

[107] T. Theophanides and J. Anastassopoulou, "Copper and carcinogenesis," Critical Reviews in Oncology/Hematology, vol. 42, no. 1, pp. 57-64, 2002.

[108] M. Valko, C. J. Rhodes, J. Moncol, M. Izakovic, and M. Mazur, "Free radicals, metals and antioxidants in oxidative stressinduced cancer," Chemico-Biological Interactions, vol. 160, no. 1, pp. 1-40, 2006. 
[109] M. Valko, D. Leibfritz, J. Moncol, M. T. D. Cronin, M. Mazur, and J. Telser, "Free radicals and antioxidants in normal physiological functions and human disease," International Journal of Biochemistry and Cell Biology, vol. 39, no. 1, pp. 44-84, 2007.

[110] J. Rudolf, V. Makrantoni, W. J. Ingledew, M. J. R. Stark, and M. F. White, "The DNA repair helicases XPD and FancJ have essential iron-sulfur domains," Molecular Cell, vol. 23, no. 6, pp. 801-808, 2006.

[111] R. Aspinwall, D. G. Rothwell, T. Roldan-Arjona et al., "Cloning and characterization of a functional human homolog of Escherichia coli endonuclease III," Proceedings of the National Academy of Sciences of the United States of America, vol. 94, no. 1, pp. 109-114, 1997.

[112] J. R. Conner and S. A. Benkovic, "Iron regulation in the brain: histochemical, biochemical, and molecular consideration," Annals of Neurology, vol. 32, supplement 1, pp. S51-S61, 1992.

[113] D. A. Loeffler, J. R. Connor, P. L. Juneau et al., “Transferrin and iron in normal, Alzheimer's disease, and Parkinson's disease brain regions," Journal of Neurochemistry, vol. 65, no. 2, pp. 710716, 1995.

[114] S. R. Pasricha, "Should we screen for iron deficiency anaemia? A review of the evidence and recent recommendations," Pathology, vol. 44, no. 2, pp. 139-147, 2012.

[115] J. Montupil and J. L. Vincent, "Magnesium in critical care and anesthesiologia," Revue medicale de Bruxelles, vol. 33, no. 5, pp. 466-474, 2012.

[116] T. Kuno, Y. Hatano, H. Tomita et al., "Organomagnesium suppresses inflammation-associated colon carcinogenesis in male Crj: CD-1 mice," Carcinogenesis, vol. 34, no. 2, pp. 361-369, 2013.

[117] M. Barbagallo, L. J. Dominguez, A. Galioto et al., "Role of magnesium in insulin action, diabetes and cardio-metabolic syndrome X," Molecular Aspects of Medicine, vol. 24, no. 1-3, pp. 39-52, 2003.

[118] M. Houston, "The role of magnesium in hypertension and cardiovascular disease," Journal of Clinical Hypertension, vol. 13, no. 11, pp. 843-847, 2011.

[119] A. Rosanoff, C. M. Weaver, and R. K. Rude, "Suboptimal magnesium status in the United States: are the health consequences underestimated?" Nutrition Reviews, vol. 70, no. 3, pp. 153-164, 2012.

[120] K. Pasternak, J. Kocot, and A. Horecka, "Biochemistry of magnesium," Journal of Elementology, vol. 15, no. 3, pp. 601-616, 2010.

[121] S. Adhikari, J. A. Toretsky, L. Yuan, and R. Roy, "Magnesium, essential for base excision repair enzymes, inhibits substrate binding of N-methylpurine-DNA glycosylase," Journal of Biological Chemistry, vol. 281, no. 40, pp. 29525-29532, 2006.

[122] E. Ma, S. Sasazuki, M. Inoue et al., "High dietary intake of magnesium may decrease risk of colorectal cancer in Japanese men," Journal of Nutrition, vol. 140, no. 4, pp. 779-785, 2010.

[123] P. A. van den Brandt, K. M. Smits, R. A. Goldbohm, and M. P. Weijenberg, "Magnesium intake and colorectal cancer risk in the Netherlands Cohort Study," British Journal of Cancer, vol. 96, no. 3, pp. 510-513, 2007.

[124] E. S. Ford and A. H. Mokdad, "Dietary magnesium intake in a national sample of U.S. adults," Journal of Nutrition, vol. 133, no. 9, pp. 2879-2882, 2003.

[125] L. Schomburg, U. Schweizer, and J. Köhrle, "Selenium and selenoproteins in mammals: extraordinary, essential, enigmatic," Cellular and Molecular Life Sciences, vol. 61, no. 16, pp. 1988-1995, 2004.
[126] R. Muecke, L. Schomburg, J. Buentzel, K. Kisters, and O. Micke, "Selenium or no selenium-that is the question in tumor patients: a new controversy," Integrative Cancer Therapies, vol. 9, no. 2, pp. 136-141, 2010.

[127] G. V. Kryukov, R. A. Kumar, A. Koc, Z. Sun, and V. N. Gladyshev, "Selenoprotein R is a zinc-containing stereo-specific methionine sulfoxide reductase," Proceedings of the National Academy of Sciences of the United States of America, vol. 99, no. 7, pp. 4245-4250, 2002.

[128] Y. Saito and K. Takahashi, "Characterization of selenoprotein P as a selenium supply protein," European Journal of Biochemistry, vol. 269, no. 22, pp. 5746-5751, 2002.

[129] A. U. Bräuer and N. E. Savaskan, "Molecular actions of selenium in the brain: neuroprotective mechanisms of an essential trace element," Reviews in the Neurosciences, vol. 15, no. 1, pp. 19-32, 2004.

[130] L. V. Papp, J. Lu, A. Holmgren, and K. K. Khanna, "From selenium to selenoproteins: synthesis, identity, and their role in human health," Antioxidants and Redox Signaling, vol. 9, no. 7, pp. 775-806, 2007.

[131] M. P. Rayman, "The importance of selenium to human health," The Lancet, vol. 356, no. 9225, pp. 233-241, 2000.

[132] G. Mugesh, W. W. Du Mont, and H. Sies, "Chemistry of biologically important synthetic organoselenium compounds," Chemical Reviews, vol. 101, no. 7, pp. 2125-2179, 2001.

[133] C. W. Nogueira, G. Zeni, and J. B. T. Rocha, "Organoselenium and organotellurium compounds: toxicology and pharmacology," Chemical Reviews, vol. 104, no. 12, pp. 6255-6285, 2004.

[134] R. M. Rosa, R. Roesler, A. L. Braga, J. Saffi, and J. A. P. Henriques, "Pharmacology and toxicology of diphenyl diselenide in several biological models," Brazilian Journal of Medical and Biological Research, vol. 40, no. 10, pp. 1287-1304, 2007.

[135] M. D. S. Machado, I. V. Villela, D. J. Moura et al., "3/3Ditrifluoromethyldiphenyl diselenide: a new organoselenium compound with interesting antigenotoxic and antimutagenic activities," Mutation Research, vol. 673, no. 2, pp. 133-140, 2009.

[136] A. Hartwig, H. Blessing, T. Schwerdtle, and I. Walter, "Modulation of DNA repair processes by arsenic and selenium compounds," Toxicology, vol. 193, no. 1-2, pp. 161-167, 2003.

[137] E. Millan Adame, D. Florea, L. Saez Perez et al., "Deficient selenium status of a healthy adult Spanish population," Nutrición Hospitalaria, vol. 27, no. 2, pp. 524-528, 2012.

[138] J. E. Spallholz, "On the nature of selenium toxicity and carcinostatic activity," Free Radical Biology and Medicine, vol. 17, no. 1, pp. 45-64, 1994.

[139] K. H. Brown, J. M. Peerson, J. Rivera, and L. H. Allen, "Effect of supplemental zinc on the growth and serum zinc concentrations of prepubertal children: a meta-analysis of randomized controlled trials," American Journal of Clinical Nutrition, vol. 75, no. 6, pp. 1062-1071, 2002.

[140] R. Puca, L. Nardinocchi, M. Porru et al., "Restoring p53 active conformation by zinc increases the response of mutant p53 tumor cells to anticancer drugs," Cell Cycle, vol. 10, no. 10, pp. 1679-1689, 2011.

[141] L. R. Ferguson and M. F. Fenech, "Vitamin and minerals that influence genome integrity, and exposure/intake levels associated with DNA damage prevention," Mutation Research, vol. 733, no. 1-2, pp. 1-3, 2012.

[142] S. Lynch, "Case studies: iron," American Journal of Clinical Nutrition, vol. 94, supplement 2, pp. 673S-678S, 2011. 
[143] D. J. Morath and M. Mayer-Pröschel, "Iron modulates the differentiation of a distinct population of glial precursor cells into oligodendrocytes," Developmental Biology, vol. 237, no. 1, pp. 232-243, 2001.

[144] T. Lindl, Zell- Und Gewebekultur, Spektrum Akademischer, Heidelberg, Germany, 5th edition, 2002.

[145] M. A. Ross, L. K. Crosley, K. M. Brown et al., "Plasma concentrations of carotenoids and antioxidant vitamins in Scottish males: influences of smoking," European Journal of Clinical Nutrition, vol. 49, no. 11, pp. 861-865, 1995.

[146] D. M. Mock and M. I. Malik, "Distribution of biotin in human plasma: most of the biotin is not bound to protein," American Journal of Clinical Nutrition, vol. 56, no. 2, pp. 427-432, 1992.

[147] A. Brevik, S. E. Vollset, G. S. Tell et al., "Plasma concentration of folate as a biomarker for the intake of fruit and vegetables: the Hordaland homocysteine study," American Journal of Clinical Nutrition, vol. 81, no. 2, pp. 434-439, 2005.

[148] R. Carmel, "Biomarkers of cobalamin (vitamin B-12) status in the epidemiologic setting: a critical overview of context, applications, and performance characteristics of cobalamin, methylmalonic acid, and holotranscobalamin II," American Journal of Clinical Nutrition, vol. 94, supplement 1, pp. 348S358S, 2011.

[149] K. Hensley, E. J. Benaksas, R. Bolli et al., "New perspectives on vitamin E: $\gamma$-tocopherol and carboxyethylhydroxychroman metabolites in biology and medicine," Free Radical Biology and Medicine, vol. 36, no. 1, pp. 1-15, 2004.

[150] J. F. Sullivan, A. J. Blotcky, and M. M. Jetton, "Serum levels of selenium, calcium, copper magnesium, manganese and zinc in various human diseases," Journal of Nutrition, vol. 109, no. 8, pp. 1432-1437, 1979.

[151] H. Cunzhi, J. Jiexian, Z. Xianwen, G. Jingang, Z. Shumin, and D. Lili, "Serum and tissue levels of six trace elements and copper/zinc ratio in patients with cervical cancer and uterine myoma," Biological Trace Element Research, vol. 94, no. 2, pp. 113-122, 2003.

[152] D. Jayme, T. Watanabe, and T. Shimada, "Basal medium development for serum-free culture: a historical perspective," Cytotechnology, vol. 23, no. 1-3, pp. 95-101, 1997.

[153] J. van der Valk, D. Mellor, R. Brands et al., "The humane collection of fetal bovine serum and possibilities for serum-free cell and tissue culture," Toxicology in Vitro, vol. 18, no. 1, pp. 1-12, 2004.

[154] H. Cohly, H. Cohly, J. Stephens et al., "Cell culture conditions affect LPS inducibility of the inflammatory mediators in J774A.1 murine macrophages," Immunological Investigations, vol. 30, no. 1, pp. 1-15, 2001.

[155] S. Proulx, S. Landreville, S. L. Guérin, and C. Salesse, "Integrin $\alpha 5$ expression by the ARPE-19 cell line: comparison with primary RPE cultures and effect of growth medium on the $\alpha 5$ gene promoter strength," Experimental Eye Research, vol. 79, no. 2, pp. 157-165, 2004.

[156] J. Tian, K. Ishibashi, S. Honda, S. A. Boylan, L. M. Hjelmeland, and J. T. Handa, "The expression of native and cultured human retinal pigment epithelial cells grown in different culture conditions," British Journal of Ophthalmology, vol. 89, no. 11, pp. 1510-1517, 2005.

[157] A. Shahdadfar, K. Frønsdal, T. Haug, F. P. Reinholt, and J. E. Brinchmann, "In vitro expansion of human mesenchymal stem cells: choice of serum is a determinant of cell proliferation, differentiation, gene expression, and transcriptome stability," Stem Cells, vol. 23, no. 9, pp. 1357-1366, 2005.
[158] K. Turnovcova, K. Ruzickova, V. Vanecek, E. Sykova, and P. Jendelova, "Properties and growth of human bone marrow mesenchymal stromal cells cultivated in different media Expansion of MSC in different media," Cytotherapy, vol. 11, no. 7, pp. 874$885,2009$.

[159] Y. G. J. van Helden, J. Keijer, S. G. Heil et al., "Beta-carotene affects oxidative stress-related DNA damage in lung epithelial cells and in ferret lung," Carcinogenesis, vol. 30, no. 12, pp. 20702076, 2009.

[160] Y. G. J. van Helden, J. Keijer, A. M. Knaapen et al., “ $\beta$ Carotene metabolites enhance inflammation-induced oxidative DNA damage in lung epithelial cells," Free Radical Biology and Medicine, vol. 46, no. 2, pp. 299-304, 2009.

[161] T. Bergstrom, J. Bergman, and L. Moller, "Vitamin A and C compounds permitted in supplements differ in their abilities to affect cell viability, DNA and the DNA nucleoside deoxyguanosine," Mutagenesis, vol. 26, no. 6, pp. 735-744, 2011.

[162] S. H. Jang, J. W. Lim, and H. Kim, "Mechanism of $\beta$-caroteneinduced apoptosis of gastric cancer cells: involvement of ataxiatelangiectasia-mutated," Annals of the New York Academy of Sciences, vol. 1171, pp. 156-162, 2009.

[163] E. Yurtcu, O. D. Iseri, and F. I. Sahin, "Effects of ascorbic acid and beta-carotene on HepG2 human hepatocellular carcinoma cell line," Molecular Biology Reports, vol. 38, no. 7, pp. 42654272, 2011.

[164] G. D. Zhou, M. Richardson, I. S. Fazili et al., "Role of retinoic acid in the modulation of benzo(a)pyrene-DNA adducts in human hepatoma cells: implications for cancer prevention," Toxicology and Applied Pharmacology, vol. 249, no. 3, pp. 224230, 2010.

[165] K. C. Manthey, J. B. Griffin, and J. Zempleni, "Biotin supply affects expression of biotin transporters, biotinylation of carboxylases and metabolism of interleukin-2 in Jurkat cells," Journal of Nutrition, vol. 132, no. 5, pp. 887-892, 2002.

[166] H. L. Lin, C. J. Chen, W. C. Tsai, J. H. Yen, and H. W. Liu, "In vitro folate deficiency induces apoptosis by a p53, Fas (Apo-1, CD95) independent, bcl-2 related mechanism in phytohaemagglutinin-stimulated human peripheral blood lymphocytes," British Journal of Nutrition, vol. 95, no. 5, pp. 870878, 2006.

[167] J. A. Reidy, "Folate- and deoxyuridine-sensitive chromatid breakage may result from DNA repair during G2," Mutation Research, vol. 192, no. 3, pp. 217-219, 1987.

[168] K. Sato, J. Kanno, T. Tominaga, Y. Matsubara, and S. Kure, "De novo and salvage pathways of DNA synthesis in primary cultured neurall stem cells," Brain Research, vol. 1071, no. 1, pp. 24-33, 2006.

[169] D. Y. Jia, H. J. Liu, F. W. Wang et al., "Folic acid supplementation affects apoptosis and differentiation of embryonic neural stem cells exposed to high glucose," Neuroscience Letters, vol. 440, no. 1, pp. 27-31, 2008.

[170] M. Kikuchi, S. Kashii, Y. Honda, Y. Tamura, K. Kaneda, and A. Akaike, "Protective effects of methylcobalamin, a vitamin B12 analog, against glutamate-induced neurotoxicity in retinal cell culture," Investigative Ophthalmology and Visual Science, vol. 38, no. 5, pp. 848-854, 1997.

[171] G. R. McLean, E. V. Quadros, S. P. Rothenberg, A. C. Morgan, J. W. Schrader, and H. J. Ziltener, "Antibodies to transcobalamin II block in vitro proliferation of leukemic cells," Blood, vol. 89, no. 1, pp. 235-242, 1997.

[172] T. L. Duarte, G. M. Almeida, and G. D. D. Jones, "Investigation of the role of extracellular $\mathrm{H}_{2} \mathrm{O}_{2}$ and transition metal ions in 
the genotoxic action of ascorbic acid in cell culture models," Toxicology Letters, vol. 170, no. 1, pp. 57-65, 2007.

[173] M. Sugiyama, K. Tsuzuki, and R. Ogura, "Effect of ascorbic acid on DNA damage, cytotoxicity, glutathione reductase, and formation of paramagnetic chromium in Chinese hamster V-79 cells treated with sodium chromate (VI)," Journal of Biological Chemistry, vol. 266, no. 6, pp. 3383-3386, 1991.

[174] M. S. Stewart, G. S. Cameron, and B. C. Pence, "Antioxidant nutrients protect against UVB-induced oxidative damage to DNA of mouse keratinocytes in culture," Journal of Investigative Dermatology, vol. 106, no. 5, pp. 1086-1089, 1996.

[175] S. F. Sweetman, J. J. Strain, and V. J. McKelvey-Martin, "Effect of antioxidant vitamin supplementation on DNA damage and repair in human lymphoblastoid cells," Nutrition and Cancer, vol. 27, no. 2, pp. 122-130, 1997.

[176] S. Abid-Essefi, I. Baudrimont, W. Hassen et al., "DNA fragmentation, apoptosis and cell cycle arrest induced by zearalenone in cultured DOK, Vero and Caco- 2 cells: prevention by Vitamin E," Toxicology, vol. 192, no. 2-3, pp. 237-248, 2003.

[177] T. H. Hung, S. F. Chen, M. J. Li, Y. L. Yeh, and T. T. Hsieh, "Differential effects of concomitant use of vitamins $\mathrm{C}$ and $\mathrm{E}$ on trophoblast apoptosis and autophagy between normoxia and hypoxia-reoxygenation," PLoS One, vol. 5, no. 8, Article ID e12202, 2010.

[178] P. Palozza, S. Serini, F. Di Nicuolo, E. Piccioni, and G. Calviello, "Prooxidant effects of $\beta$-carotene in cultured cells," Molecular Aspects of Medicine, vol. 24, no. 6, pp. 353-362, 2003.

[179] R. Rodriguez-Melendez and J. Zempleni, "Regulation of gene expression by biotin," Journal of Nutritional Biochemistry, vol. 14, no. 12, pp. 680-690, 2003.

[180] S. W. Choi and J. B. Mason, "Folate and carcinogenesis: an integrated scheme," Journal of Nutrition, vol. 130, no. 2, pp. 129$132,2000$.

[181] P. J. Stover, "Physiology of folate and vitamin B12 in health and disease," Nutrition Reviews, vol. 62, supplement 6, pp. S3-S13, 2004.

[182] O. Bashir, A. J. FitzGerald, and R. A. Goodlad, "Both suboptimal and elevated vitamin intake increase intestinal neoplasia and alter crypt fission in the ApcMin/+ mouse," Carcinogenesis, vol. 25, no. 8, pp. 1507-1515, 2004.

[183] M. G. Traber and J. F. Stevens, "Vitamins C and E: beneficial effects from a mechanistic perspective," Free Radical Biology and Medicine, vol. 51, no. 5, pp. 1000-1013, 2011.

[184] R. Seth, S. Yang, S. Choi, M. Sabean, and E. A. Roberts, "In vitro assessment of copper-induced toxicity in the human hepatoma line, Hep G2," Toxicology in Vitro, vol. 18, no. 4, pp. 501-509, 2004.

[185] C. A. Grillo, M. A. Reigosa, and M. A. Fernández Lorenzo de Mele, "Does over-exposure to copper ions released from metallic copper induce cytotoxic and genotoxic effects on mammalian cells?” Contraception, vol. 81, no. 4, pp. 343-349, 2010.

[186] C. Lin, J. Kang, and R. Zheng, "Oxidative stress is involved in inhibition of copper on histone acetylation in cells," ChemicoBiological Interactions, vol. 151, no. 3, pp. 167-176, 2005.

[187] P. D. L. Lima, M. C. Vasconcellos, R. A. Montenegro et al., "Genotoxic and cytotoxic effects of iron sulfate in cultured human lymphocytes treated in different phases of cell cycle," Toxicology in Vitro, vol. 22, no. 3, pp. 723-729, 2008.

[188] Y. M. Pu, Q. Wang, and Z. M. Qian, "Effect of iron and lipid peroxidation on development of cerebellar granule cells in vitro," Neuroscience, vol. 89, no. 3, pp. 855-861, 1999.
[189] Y. Knöbel, A. Weise, M. Glei, W. Sendt, U. Claussen, and B. L. Pool-Zobel, "Ferric iron is genotoxic in non-transformed and preneoplastic human colon cells," Food and Chemical Toxicology, vol. 45, no. 5, pp. 804-811, 2007.

[190] J. A. M. Maier, C. Malpuech-Brugère, W. Zimowska, Y. Rayssiguier, and A. Mazur, "Low magnesium promotes endothelial cell dysfunction: implications for atherosclerosis, inflammation and thrombosis," Biochimica et Biophysica Acta, vol. 1689, no. 1, pp. 13-21, 2004.

[191] A. Sgambato, F. I. Wolf, B. Faraglia, and A. Cittadini, "Magnesium depletion causes growth inhibition, reduced expression of cyclin D1, and increased expression of P27Kip1 in normal but not in transformed mammary epithelial cells," Journal of Cellular Physiology, vol. 180, no. 2, pp. 245-254, 1999.

[192] D. W. Killilea and B. N. Ames, "Magnesium deficiency accelerates cellular senescence in cultured human fibroblasts," Proceedings of the National Academy of Sciences of the United States of America, vol. 105, no. 15, pp. 5768-5773, 2008.

[193] P. Calsou and B. Salles, "Properties of damage-dependent DNA incision by nucleotide excision repair in human cell-free extracts," Nucleic Acids Research, vol. 22, no. 23, pp. 4937-4942, 1994.

[194] C. S. Hoefig, K. Renko, J. Kohrle, M. Birringer, and L. Schomburg, "Comparison of different selenocompounds with respect to nutritional value vs. toxicity using liver cells in culture," The Journal of Nutritional Biochemistry, vol. 22, no. 10, pp. 945-955, 2011.

[195] H. Zeng, M. Wu, and J. H. Botnen, "Methylselenol, a selenium metabolite, induces cell cycle arrest in G1 phase and apoptosis via the extracellular-regulated kinase $1 / 2$ pathway and other cancer signaling genes," Journal of Nutrition, vol. 139, no. 9, pp. 1613-1618, 2009.

[196] S. Cuello, S. Ramos, R. Mateos et al., "Selenium methylselenocysteine protects human hepatoma HepG2 cells against oxidative stress induced by tert-butyl hydroperoxide," Analytical and Bioanalytical Chemistry, vol. 389, no. 7-8, pp. 2167-2178, 2007.

[197] M. H. Helmy, S. S. Ismail, H. Fayed, and E. A. El-Bassiouni, "Effect of selenium supplementation on the activities of glutathione metabolizing enzymes in human hepatoma Hep G2 cell line," Toxicology, vol. 144, no. 1-3, pp. 57-61, 2000.

[198] E. Ho and B. N. Ames, "Low intracellular zinc induces oxidative DNA damage, disrupts $\mathrm{p} 53, \mathrm{NF} \kappa \mathrm{B}$, and AP1 DNA binding, and affects DNA repair in a rat glioma cell line," Proceedings of the National Academy of Sciences of the United States of America, vol. 99, no. 26, pp. 16770-16775, 2002.

[199] R. Sharif, P. Thomas, P. Zalewski, R. D. Graham, and M. Fenech, "The effect of zinc sulphate and zinc carnosine on genome stability and cytotoxicity in the WIL2-NS human lymphoblastoid cell line," Mutation Research, vol. 720, no. 1-2, pp. 22-33, 2011.

[200] R. Sharif, P. Thomas, P. Zalewski, and M. Fenech, "Zinc deficiency or excess within the physiological range increases genome instability and cytotoxicity, respectively, in human oral keratinocyte cells," Genes \& Nutrition, vol. 7, no. 2, pp. 139-154, 2012.

[201] S. Sergeant and W. T. Johnson, "Iron and copper requirements for proliferation and differentiation of a human promyelocytic leukemia cell line (HL-60)," Journal of Cellular Physiology, vol. 163, no. 3, pp. 477-485, 1995.

[202] F. I. Wolf, A. Torsello, S. Fasanella, and A. Cittadini, "Cell physiology of magnesium," Molecular Aspects of Medicine, vol. 24, no. 1-3, pp. 11-26, 2003. 
[203] B. F. Dickens, W. B. Weglicki, Y. S. Li, and I. T. Mak, "Magnesium deficiency in vitro enhances free radical-induced intracellular oxidation and cytotoxicity in endothelial cells," FEBS Letters, vol. 311, no. 3, pp. 187-191, 1992.

[204] H. Martin, C. Abadie, B. Heyd, G. Mantion, L. Richert, and A. Berthelot, "N-acetylcysteine partially reverses oxidative stress and apoptosis exacerbated by Mg-deficiency culturing conditions in primary cultures of rat and human hepatocytes," Journal of the American College of Nutrition, vol. 25, no. 5, pp. 363-369, 2006.

[205] Y. Yang, Z. Wu, Y. Chen et al., "Magnesium deficiency enhances hydrogen peroxide production and oxidative damage in chick embryo hepatocyte in vitro," BioMetals, vol. 19, no. 1, pp. 71-81, 2006.

[206] S. Ferrè, A. Mazur, and J. A. M. Maier, "Low-magnesium induces senescent features in cultured human endothelial cells," Magnesium Research, vol. 20, no. 1, pp. 66-71, 2007.

[207] W. L. McKeehan and R. G. Ham, "Calcium and magnesium ions and the regulation of multiplication in normal and transformed cells," Nature, vol. 275, no. 5682, pp. 756-758, 1978.

[208] R. Sharif, P. Thomas, P. Zalewski, and M. Fenech, "The role of zinc in genomic stability," Mutation Research, vol. 733, no. 1-2, pp. 111-121, 2012.

[209] J. van der Valk, D. Brunner, K. De Smet et al., "Optimization of chemically defined cell culture media-replacing fetal bovine serum in mammalian in vitro methods," Toxicology in Vitro, vol. 24, no. 4, pp. 1053-1063, 2010.

[210] X. Zheng, H. Baker, W. S. Hancock, F. Fawaz, M. McCaman, and E. Pungor Jr., "Proteomic analysis for the assessment of different lots of fetal bovine serum as a raw material for cell culture. Part IV. Application of proteomics to the manufacture of biological drugs," Biotechnology Progress, vol. 22, no. 5, pp. 1294-1300, 2006.

[211] A. Jacobs, T. Hoy, J. Humphrys, and P. Perera, "Iron overload in chang cell cultures: biochemical and morphological studies," British Journal of Experimental Pathology, vol. 59, no. 5, pp. 489498, 1978. 

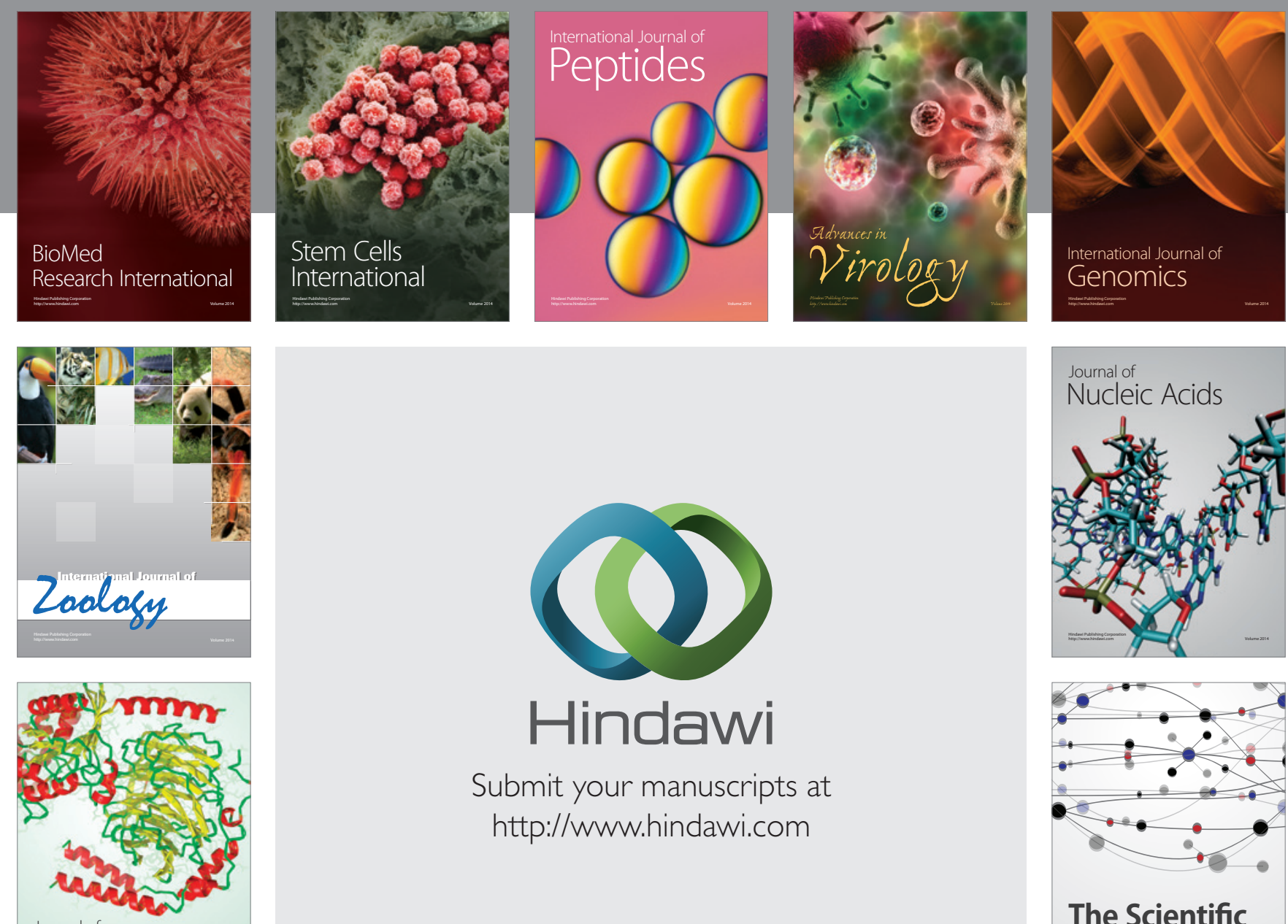

Submit your manuscripts at

http://www.hindawi.com

Journal of
Signal Transduction
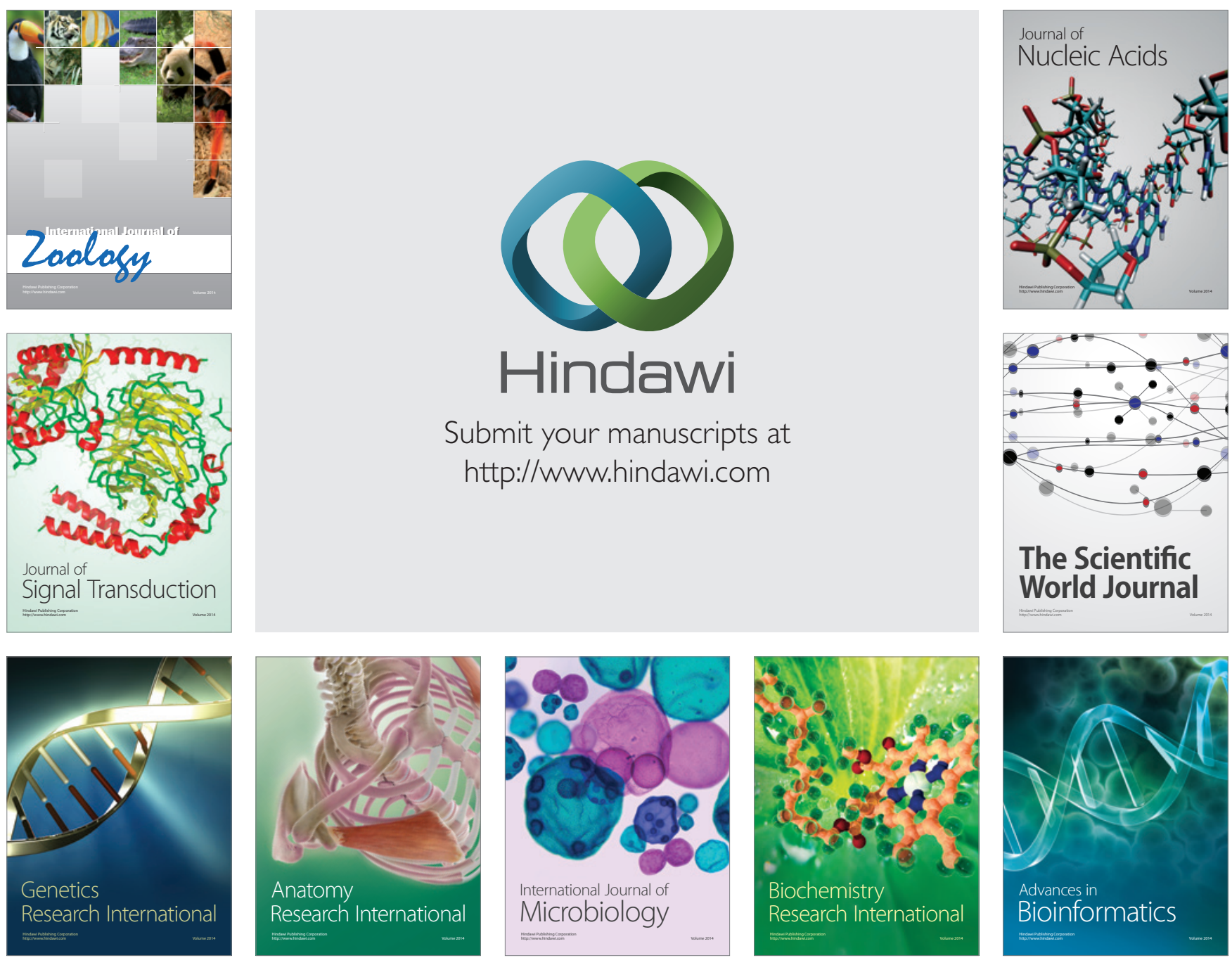

The Scientific World Journal
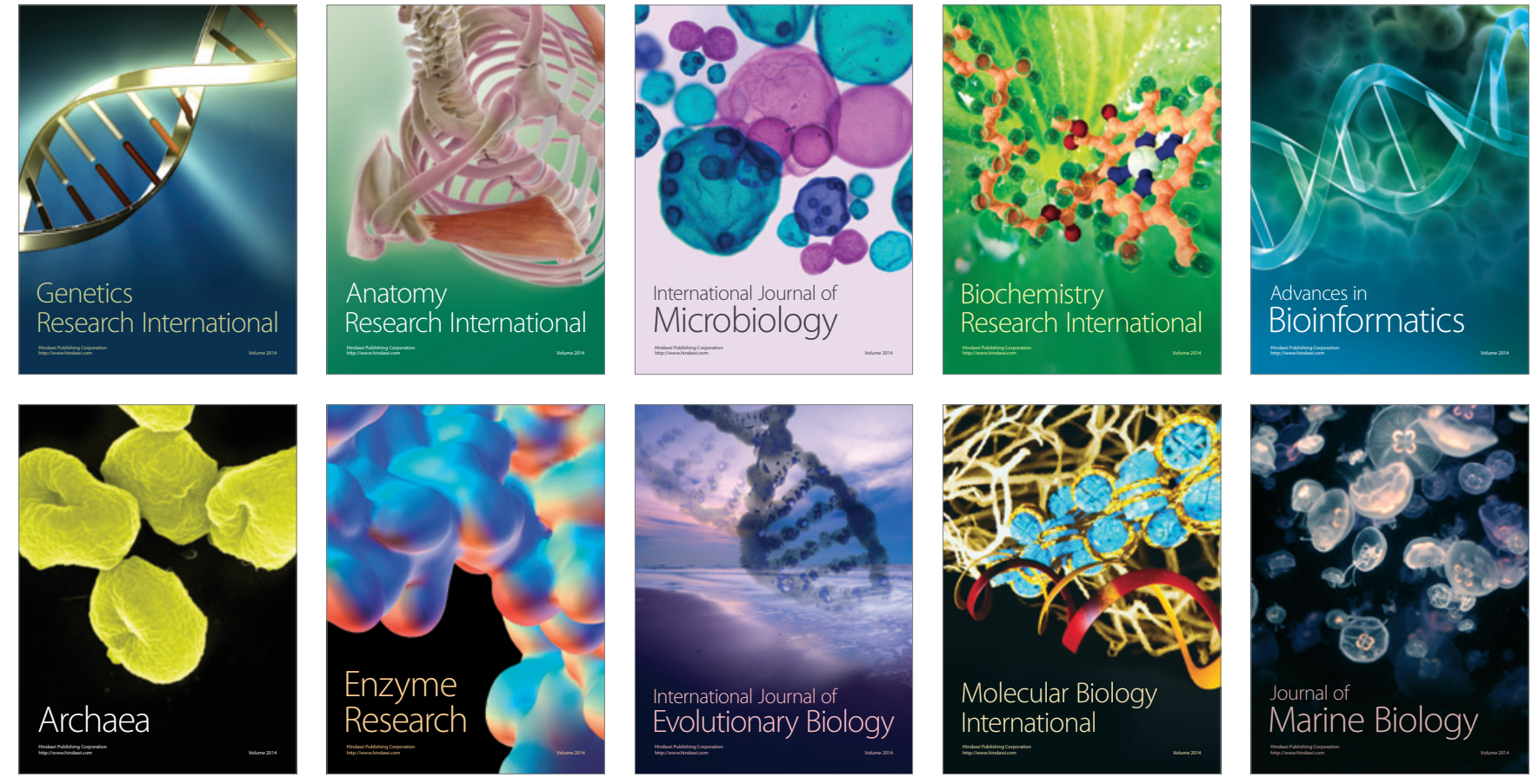